Federal Reserve Bank of Minneapolis

Research Department

\title{
Capital Market Imperfections, International Credit Markets, and Nonconvergence
}

\author{
John H. Boyd and Bruce D. Smith*
}

Working Paper 522

Revised November 1995

*Boyd, Federal Reserve Bank of Minneapolis and University of Minnesota; Smith, Cornell University and Federal Reserve Bank of Minneapolis. We thank Valerie Bencivenga for some very helpful suggestions, Joel Krueger for excellent research assistance, and the participants of seminars at the University of Amsterdam, Carnegie-Mellon, Columbia, George Washington, Montreal, Indiana, Iowa, Northwestern, Penn State, Rutgers, UCLA, UC-Riverside, and UC-San Diego, and the Federal Reserve Banks of Atlanta, Minneapolis, and Philadelphia, as well as conferences at New York University, San Sebastian (C.E.P.R.), and the Federal Reserve Bank of Dallas-especially Russell Cooper, Ross Levine, and Bob Moore-for very helpful comments on an earlier draft of this paper. We also thank an associate editor and two anonymous referees for their constructive suggestions. The views expressed herein are those of the authors and not necessarily those of the Federal Reserve Bank of Minneapolis or the Federal Reserve System. 



\begin{abstract}
We consider a two country growth model with international capital markets. These markets fund capital investment in both countries, and operate subject to a costly state verification (CSV) problem. Investors in each country require some external finance, but also provide internal finance, which mitigates the CSV problem. When two identical (except for their initial capital stocks) economies are closed, they necessarily converge monotonically to the same steady state output level. Unrestricted international financial trade precludes otherwise identical economies from converging, and poor countries are necessarily net lenders to rich countries. Oscillation in real activity and international capital flows can occur.
\end{abstract}





\section{Introduction}

Many less-developed economies receive little or no (private) credit from other countries. ${ }^{1}$ Thus to the extent that their residents hold bank deposits-or otherwise extend credit-abroad, and to the extent that this credit finances capital investment, the international allocation of credit works against the international equalization of capital stocks and production levels.

Many less-developed economies also seek, effectively, to close off their financial markets, often limiting both inflows and outflows of funds. ${ }^{2}$ And, indeed, it is often deemed desirable that they should do so. ${ }^{3}$ This observation raises an obvious question: what are the consequences-for either poor or wealthy economies-of opening themselves to international trade in financial assets? The answer to this question obviously involves the analysis of two issues: how does the operation of international capital markets affect long-run capital accumulation across different countries, and how does it affect the shorter-term volatility of both real activity, and of international capital flows?

We consider these questions in the context of an open economy version of the Diamond [14] model, in which agents who engage in capital production must combine their own funds with credit obtained externally (either in their own country, or abroad). In addition, the allocation of credit is complicated by the presence of a costly state verification (CSV) problem, of the type introduced by Townsend [30]. We consider an environment in which this CSV problem leads to credit rationing, as in Gale and Hellwig [17] or Williamson [33, 34]. In this framework, the answer to our initial question is a surprising one: opening international credit markets tends to make initially poor economies poor permanently. Moreover, international borrowing and lending is a potential source of endogenous cyclical fluctuations in both real activity and in international asset flows. This cannot occur when international financial markets 
are closed (and it cannot occur without a financial market friction). Thus, in the presence of informational asymmetries which lead to credit rationing, the opening of international capital markets can be a source of permanent income inequality and enhanced cyclical fluctuations.

To be more specific, we obtain these results in a two country version of Diamond's [14] model in which the two countries are identical in every respect but one. Each of the countries produces a single (perishable) consumption good using the same constant returns to scale technology with capital and labor as inputs. Factors of production are assumed to be immobile, so that all trade between the economies is financial. ${ }^{4}$ Finally, each country has an identical population at each date, with the following features. All agents supply one unit of labor when young, thereby earning labor income, and are retired when old. Some of these agents have access to investment projects which convert time t goods into time $t+1$ capital in a stochastic manner. These agents combine their own funds with external credit in order to finance capital investments. Other agents have no access to the capital production technology, and these individuals simply lend their funds (through intermediaries) to agents who can undertake capital investments. The allocation of this credit is complicated by a CSV problem; only the initiating investor can freely observe the outcome of any specific capital investment. Other agents can observe this by incurring a fixed cost. The capital production technology is identical across countries, as is the CSV problem. Thus the two countries differ, if at all, only with respect to their initial capital stocks.

We construct the model so that, when each economy is closed, there exists a unique, asymptotically stable, nontrivial steady state equilibrium. Dynamical equilibria display monotonic convergence to this steady state from any given (positive) initial capital stock. Thus, asymptotically, each economy approaches the same per capita capital stock and income level. 
The economies converge, and can display no economic fluctuations as they do so. The only qualitative consequence of the informational asymmetry is that it leads to a reduction in the steady state capital stock, relative to its full information level.

When international credit markets are open, however, matters are substantially different. Under some technical conditions, we show that the existence of open international financial markets results in the existence of at least three nontrivial steady states. One of these is "symmetric;" the two economies have the same steady state capital stock, which coincides with the unique nontrivial steady state capital stock of the closed economy model. In this steady state, there are zero net capital flows internationally.

The other nontrivial steady states are "asymmetric;" they have one country with a permanently higher capital stock, income, and output level than the other. In an asymmetric steady state, the rich country is necessarily wealthier and the poor country is necessarily less wealthy than they would be in the symmetric state. In addition, the asymmetric steady state has a lower world capital stock than the symmetric steady state, and it has the feature that the poor country is a net lender to the rich country. Thus the international allocation of credit is necessarily perverse. ${ }^{5}$

This situation is possible because differences in capital stocks across countries affect the labor incomes of capital investors, and hence affect their ability to provide internal financing of their investment projects. As is well-known [2], the ability of capital investors to provide additional internal finance tends to mitigate the CSV problem. Thus a country with a high capital stock will have a superior ability to internally finance investments, ceteris paribus, and this makes a wealthier economy a more attractive home for lenders. This effect counteracts the fact that the country with a high capital stock has a low marginal product of capital. In an 
asymmetric steady state these two effects exactly balance each other, permitting one country to have a permanently higher capital stock than the other. Moreover, under our assumptions, in such a steady state there is necessarily net investment by the poorer country in the wealthier country. This is the case despite the absence of any political or legal factors that would tend to result in capital flight, or any diversification motive on the part of investors.

Given the proliferation of steady states in the model, it is important to ask about their (local) stability properties. By specializing to the case of Cobb-Douglas production we are able to show that the symmetric steady state is a saddle; the saddle path has the capital stocks in the two countries being identical at each date. Thus, if the two economies have the same initial capital stocks, they will have identical capital stocks forever, and both economies will converge monotonically to the symmetric steady state capital stock and income level. On the other hand, it is possible to show that if the two economies have different initial capital stocks, the economies cannot converge to the same capital stock or output level. In addition, we produce a sufficient condition for the asymmetric steady states to be sinks, as well as a set of examples where the asymmetric steady states have this property. For these examples, economies that have initial capital stocks near these steady states will converge to them.

Interestingly, for many parameter values, dynamical equilibrium paths approaching these asymmetric steady states display damped oscillation. Thus the opening of international credit markets leads to the occurrence of economic fluctuations (which are impossible in closed economies, or in the absence of the CSV friction in credit markets). Therefore credit market imperfections, coupled with international financial flows, are a potential source of real economic volatility. If this arises, it will necessarily be accompanied by endogenously arising volatility in international capital flows as well. ${ }^{\circ}$ 
In summary, the combination of international financial trade, coupled with a CSV problem in credit markets, is a potential source of permanent international income inequality, a perverse international allocation of credit, and endogenous economic fluctuations. We believe that there is some preliminary empirical support for each of these theoretical findings. First, the possibility that funds flow-perversely-on net from poorer to wealthier economies is a feature of the data for the last decade. As Table 1 indicates, for each year since 1984 , developing countries have been net lenders (long-term) to the more developed countries. Second, the possibility that international financial market activity can lead to enhanced economic volatility is also widely accepted. As argued in [20, p. 50] "international lending can fluctuate wildly - with rapid increases in flows followed by even more rapid withdrawal of funds." This cyclicality of credit allocation between developing and developed economies is indeed a feature of the data, as Table 1 demonstrates. Net credit extension to developing countries in the $1970 \mathrm{~s}$ was accompanied by a reversal of this pattern in the 1980 s. Recent events can only bolster the conclusion that there is a great deal of cyclicality in international capital flows. Such cyclical variation is quite consistent with our results. Third, the model suggests that countries with high income levels can sustain their relative positions because their investors can provide a high level of internal finance for investment projects. Singh and Hamid [28] provide an array of evidence suggesting that internal financing of capital investment varies dramatically across countries, and in exactly the way that our model predicts. And, finally, at least some empirical work on convergence suggests that the lack of convergence predicted by the model is consistent with observation. Parente and Prescott [27], for example, argue that most economies display long periods where their output levels are virtually constant, relative to U.S. output. This is the kind of outcome predicted by our analysis. 
Prior to proceeding with the model, we wish to acknowledge some intellectual antecedents to our work. The model of credit rationing employed here closely follows Williamson [33, 34]. The importance of internal financing in the allocation of credit in CSV models is a theme of Bernanke and Gertler [2]. The possibility that the international allocation of credit could be perverse in the presence of informational frictions is discussed by Gertler and Rogoff [18] in a static context; we show that wealth differences across economies can be preserved indefinitely, and that the informational asymmetry has interesting dynamic consequences. ${ }^{7}$ Relatedly, the possibility that the development of financial markets could lead to (temporarily) enhanced income inequality is considered by Greenwood and Jovanovic [19]; we show that this result should be expected to prevail across countries, and to be permanent in this particular manifestation. Finally, some empirical support for the kind of model considered here is presented by Ma and Smith [25].

The remainder of the paper proceeds as follows. Section 2 describes the environment, while Section 3 considers how trade occurs and how credit is allocated. Section 4 examines the closed economy version of the model, while Section 5 describes our results for steady states when international credit markets exist. Section 5 also analyzes some of the welfare consequences of international financial trade. Section 6 considers dynamics in the open economy, and Section 7 concludes.

\section{Environment}

We consider a discrete time economy populated by an infinite sequence of two period lived, overlapping generations. At each date a set of young agents is born into each of two 
countries; we assume a continuum of young agents in each country with unit mass. Agents cannot move between countries. Throughout we let $t=0,1, \ldots$ index the date.

At each date a single final good is produced in each country, using the capital stock of that country and the labor supply of that country as inputs into production. Let $K_{1}^{\mathrm{j}}$ ( $\mathrm{i}=1,2$ ) denote the capital stock of country $i$ at $t$, and $L_{t}^{i}$ denote the quantity of labor employed in country $i$ at $t$. Then country i's time t output $-Y_{t}^{i}-i$ is given by $Y_{t}^{i}=F\left(K_{t}^{i}, L_{i}^{i}\right)$, where $F$ is a standard, commonly available, constant returns to scale production function. We assume that $F$ satisfies $\mathrm{F}(0, \mathrm{~L})=\mathrm{F}(\mathrm{K}, 0)=0$ and standard Inada conditions, and in addition that $\mathrm{F}$ is increasing in each argument and strictly concave. We further assume that factors of production are immobile between countries, and we emphasize that the same production technology is available to each country. Finally, we assume that capital depreciates completely in production each period.

Agents are endowed with one unit of labor when young, which is supplied inelastically, and are retired when old. Thus $L_{t}^{i}=1$. In addition, agents other than the initial old have no endowment of capital or the final good at any date. We assume that the initial old of country $i$ are each endowed with $K_{0}^{i}>0$ units of capital.

We assume that young agents in each country are divided into two "types," which we refer to as "borrowers" (or "potential borrowers") and "lenders." Borrowers have access to a stochastic linear technology for converting the time $t$ final good into time $t+1$ capital. Lenders have no access to such a technology.

The capital investment technology is as follows. Each borrower has access to a single, indivisible investment project. $\mathrm{q}>0$ units of the final good invested in this project at $t$ yield $\mathrm{zq}$ units of capital at $\mathrm{t}+1$. $\mathrm{z}$ is an iid (across agents) random variable which is realized at the 
beginning of $t+1$. Let $G$ be the probability distribution of $z$, with associated (differentiable) density function $\mathrm{g}$, and let $[0, \bar{z}]$ be the support of $\mathrm{g}$. Finally, we let

$$
\hat{z} \equiv \int_{0}^{\bar{z}} z g(z) d z
$$

be the expected value of $z$. Notice that this investment technology can only be operated at the scale q, that all borrowers have access to the same investment technology, and that the same capital investment technology is available in each country. Finally, let $\alpha \in(0,1)$ denote the fraction of the young population in each country comprising "borrowers." This is again identical across countries.

The capital market imperfection in this model takes the form of a standard costly state verification (CSV) problem. In particular, the realization $z$ on any investment project can be observed costlessly only by the project owner. Any other agent can observe the project realization only by bearing a fixed cost of $\gamma>0$ units of capital. ${ }^{8}$ This cost is again identical in each country.

With respect to preferences, we assume that all agents are risk neutral, and care only about old age consumption. Hence all young period income is invested in capital formation. To summarize, the two countries are identical in every respect, except possibly for their initial capital stocks.

\section{Trade}

\section{A. Factor Markets}

We assume that there are competitive rental markets for capital and labor in each country, and that factors of production are immobile between countries. The single final good 
can be traded between countries; here all trade will take the form of international borrowing and lending.

Let $w_{t}^{i}$ be the real wage rate in country $i$ at $t$, and let $\rho_{t}^{i}$ be the rental rate on capital. If we let $\mathrm{f}\left(\mathrm{k}_{\mathrm{l}}^{\mathrm{j}}\right)$ denote the intensive production function, ${ }^{9}$ and $\mathrm{k}_{\mathrm{t}}^{\mathrm{i}}$ denote the capital-labor ratio of country $\mathrm{i}\left(\mathrm{k}_{\mathrm{i}}^{\mathrm{i}} \equiv \mathrm{K}_{\mathrm{r}}^{\mathrm{i}} \mathrm{L}_{\mathrm{i}}^{\mathrm{j}}\right)$, then the standard marginal productivity conditions obtain:

$$
\begin{aligned}
& \rho_{\mathrm{t}}^{\mathrm{i}}=\mathrm{f}^{\prime}\left(\mathrm{k}_{\mathrm{t}}^{\mathrm{i}}\right) ; \quad \mathrm{i}=1,2 \\
& \mathrm{w}_{\mathrm{t}}^{\mathrm{i}}=\mathrm{f}\left(\mathrm{k}_{\mathrm{t}}^{\mathrm{j}}\right)-\mathrm{k}_{\mathrm{t}}^{\mathrm{i}} \mathrm{f}^{\prime}\left(\mathrm{k}_{\mathrm{t}}^{\mathrm{i}}\right) \equiv \mathrm{w}\left(\mathrm{k}_{\mathrm{t}}^{\mathrm{i}}\right) ; \quad \mathrm{i}=1,2 .
\end{aligned}
$$

We make one assumption on the function $w(k)$; namely that for all $k \geq 0$,

$$
w^{\prime \prime}(k)<0 \text {. }
$$

(A.1) is satisfied, for example, by any CES production function with elasticity of substitution no less than one. ${ }^{10}$

\section{B. Credit Markets}

All young agents in country i supply one unit of labor inelastically, earning the real wage rate $\mathrm{w}_{\mathrm{t}}^{\mathrm{i}}$. For lenders this income is supplied inelastically in credit markets, and we can think of all credit extension as being intermediated [33]. Potential borrowers have the same young period income, and if $\mathrm{q}>\mathrm{w}_{\mathrm{t}}^{\mathrm{i}}$, they must obtain external financing to operate their investment projects (should they wish to do so). We assume that for all relevant values (see below) of the capital stock in country $\mathrm{i}$,

$$
\mathrm{q}>\mathrm{w}\left(\mathrm{k}^{\mathrm{i}}\right)
$$

holds for all $\mathrm{t}$. Thus borrowers require external finance to operate their projects. Let $b_{\xi}^{i}$ denote borrowing by a typical borrower (who obtains financing) in country $i$ at $t$; clearly 


$$
b_{t}^{i}=q-w\left(k^{i}\right) .
$$

Assuming that borrowers wish to obtain funding (see below), they do so by announcing loan contracts in the manner described by Williamson $[33,34]$. A loan contract consists of the following set of objects. First, there is a set $A_{1}^{i}$ of project return realizations for which verification of the return occurs in country $i$ at $t^{11}$ In addition, there is a set of return realizations $B_{t}^{i}=[0, \bar{z}]-A_{t}^{i}$ for which there is no verification of the state. Second, if $z \in A_{t}^{i}$, the payment from the borrower to the lender (which is an intermediary) can meaningfully be made contingent on the project return. In this case we denote the promised (state contingent) payment (per unit borrowed) by $\mathrm{R}_{\mathrm{l}}^{\mathrm{i}}(\mathrm{z})$. If $\mathrm{z} \in \mathrm{B}_{\mathrm{t}}^{\mathrm{i}}$ the loan repayment cannot meaningfully be made contingent on the project return. Therefore the only incentive compatible loan contract offers an uncontingent repayment of $x_{t}^{i}$ (per unit borrowed) in country $i$ at $t$ if $z \in B_{t}^{i}$.

Borrowers announce loan contract terms to lenders (intermediaries). We assume that any lender can form an intermediary, which takes deposits, makes loans, and conducts monitoring of project returns as necessary. In equilibrium, intermediaries will lend to a large number of borrowers, and hence will themselves have a nonstochastic return on their portfolio. Thus the intermediary need not be monitored by its depositors.

We assume that intermediaries take the gross rate of return they must pay on deposits between $\mathrm{t}$ and $\mathrm{t}+1$-denoted $\mathrm{r}_{\mathrm{t}+1}$-as given, ${ }^{12}$ and that they believe they can obtain any quantity of funds at that rate. Then intermediaries will accept any loan contract offers yielding them an expected return of at least $r_{t+1}$. Therefore, loan contract offers (that have any prospect of acceptance) must satisfy the expected return constraint

$$
\int_{A_{t}^{i}}\left[R_{t}^{i}(z) b_{t}^{i}-\rho_{t+1}^{i} \gamma\right] g(z) d z+b_{t}^{i} x_{t}^{i} \int_{B_{t}^{i}} g(z) d z \geq r_{t+1} b_{t}^{i}
$$


Equation (4) asserts that expected repayments must at least cover the intermediary's cost of funds, inclusive of expected monitoring costs. ${ }^{13}$ The latter cost depends on the rental rate $\rho_{\mathrm{t}+1}^{\mathrm{i}}$ because $\gamma$ units of capital are consumed in monitoring, and this capital has a goods (market) value of $\rho_{\mathrm{t}+1}^{\mathrm{i}}$ in country i at $\mathrm{t}+1$. Finally, since only the borrower directly observes the state, he must have an incentive to truthfully reveal when a monitoring state has occurred. This incentive compatibility requirement is

$$
\mathrm{R}_{\mathrm{t}}^{\mathrm{i}}(\mathrm{z}) \leq \mathrm{x}_{\mathrm{t}}^{\mathrm{i}}, \quad \text { for all } \mathrm{z} \in \mathrm{A}_{\mathrm{t}}^{\mathrm{i}}
$$

Borrowers seek to maximize their own expected utility by choice of loan contract terms, subject to the constraints (4) and (5). Thus, announced loan contracts in country i solve the problem

$$
\max \left\{q \hat{z} \rho_{t+1}^{i}-b_{t}^{i} \int_{A_{t}^{i}} R_{t}^{i}(z) g(z) d z-b_{t}^{i} x_{t}^{i} \int_{B_{t}^{i}} g(z) d z\right\}
$$

subject to (4), (5), and nonnegativity; that is

$$
\begin{aligned}
& 0 \leq \mathrm{R}_{t}^{\mathrm{i}}(\mathrm{z}) \leq \mathrm{zq} \rho_{\mathrm{t}+1}^{\mathrm{i}} / \mathrm{b}_{\mathrm{t}}^{\mathrm{i}} \\
& 0 \leq \mathrm{x}_{\mathrm{t}}^{\mathrm{i}} \leq \inf _{\mathrm{z} \in \mathrm{B}_{t}^{\mathrm{i}}}\left[\mathrm{zq} \rho_{\mathrm{t}+1}^{\mathrm{i}}\right] / \mathrm{b}_{\mathrm{t}}^{\mathrm{i}} .
\end{aligned}
$$

(6) and (7) assert that the borrower cannot pay more than the goods value of his capital, which in state $\mathrm{z}$ is $\mathrm{zq} \rho_{\mathrm{t}+1}^{\mathrm{i}}$.

We now state 
Proposirion 1. The solution to the borrower's problem is a standard debt contract modified for the existence of internal finance $\left(b_{t}^{i}<q\right)$. That is, the optimal contractual loan terms are given by

$$
\begin{aligned}
& R_{t}^{i}(z)=z q \rho_{t+1}^{i} / b_{t}^{i} \\
& A_{t}^{i}=\left[0,\left(x_{t}^{i} b_{t}^{i} / q \rho_{t+1}^{i}\right)\right) \\
& \int_{A_{t}^{i}}\left[R_{t}^{i}(z)-\left(\rho_{t+1}^{i} \gamma / b_{t}^{i}\right)\right] g(z) d z+x_{t}^{i} \int_{B_{t}^{i}} g(z) d z=r_{t+1} .
\end{aligned}
$$

The proof of proposition 1 is standard (see [17], [33], or [34]) and is omitted here.

It will subsequently be useful to define the function $\pi[\mathrm{x} ;(\mathrm{b} / \rho)]$ by

$$
\begin{aligned}
\pi[\mathrm{x} ;(\mathrm{b} / \rho)] & \equiv \mathrm{x}\{1-\mathrm{G}(\mathrm{xb} / \mathrm{q} \rho)\}-(\gamma \rho / \mathrm{b}) \mathrm{G}(\mathrm{xb} / \mathrm{q} \rho)+\int_{0}^{(\mathrm{xb} / \mathrm{\rho} \rho)}(\mathrm{q} \rho / \mathrm{b}) \mathrm{zg}(\mathrm{z}) \mathrm{dz} \\
& \equiv \mathrm{x}-(\gamma \rho / \mathrm{b}) \mathrm{G}(\mathrm{xb} / \mathrm{q} \rho)-(\mathrm{q} \rho / \mathrm{b}) \int_{0}^{(\mathrm{xb} / \mathrm{q} \rho)} \mathrm{G}(\mathrm{z}) \mathrm{dz}
\end{aligned}
$$

where the last line is obtained via integration by parts. The function $\pi$ gives the expected return to a lender as a function of the contractually specified gross interest rate, $\mathrm{x}$, the degree of external finance, $b$, and the relative price of capital, $\rho$. Then clearly the contractual equilibrium interest rate in country $i$ satisfies

$$
\pi\left[\mathrm{x}_{\mathrm{t}}^{\mathrm{i}},\left(\mathrm{b}_{\mathrm{t}}^{\mathrm{i}} / \rho_{\mathrm{t}+1}^{\mathrm{i}}\right)\right]=\mathrm{r}_{\mathrm{t}+1}
$$

It will also be convenient to impose conditions implying that $\pi_{11}<0$. The appropriate primitive assumption is that ${ }^{14}$

$$
\mathrm{g}(\mathrm{z})+(\gamma / \mathrm{q}) \mathrm{g}^{\prime}(\mathrm{z}) \geq 0, \quad \text { for all } \mathrm{z} \in[0, \overline{\mathrm{z}}] \text {. }
$$


When (A.3) holds, the function $\pi$ looks as depicted in Figure 1. Evidently, there is a unique interest rate, $\hat{x}(b / \rho)$, that maximizes the expected return that can be offered to any lender. $\hat{\mathrm{x}}(\mathrm{b} / \rho)$ is defined implicitly by

$$
\pi_{1}[\hat{\mathrm{x}}(\mathrm{b} / \rho) ;(\mathrm{b} / \rho)] \equiv 1-(\gamma / \mathrm{q}) \mathrm{g}[\hat{\mathrm{x}}(\mathrm{b} / \rho)(\mathrm{b} / \mathrm{q} \rho)]-\mathrm{G}[\hat{\mathrm{x}}(\mathrm{b} / \rho)(\mathrm{b} / \mathrm{q} \rho)] \equiv 0
$$

Equation (13) and the assumption (A.3) imply that $\hat{\mathrm{x}}(\mathrm{b} / \rho)(\mathrm{b} / \mathrm{q} \rho)$ is a constant, say

$$
\hat{\mathrm{x}}(\mathrm{b} / \rho)(\mathrm{b} / \mathrm{q} \rho) \equiv \eta
$$

where $\eta$ satisfies $1-[\gamma \mathrm{g}(\eta) / \mathrm{q}]-\mathrm{G}(\eta) \equiv 0$. Note that $\eta$ is simply the auditing probability that emerges when the rate of interest charged on loans is bid up to its expected return maximizing level. The assumption that monitoring uses capital implies that $\eta$ is independent of any endogenous variables.

\section{Credit Rationing}

As noted in [17], [33], or [34], it can easily happen that there is unfulfilled demand for credit in this environment. In particular, if all potential borrowers desire to operate their projects, the demand for investment funds in each country is $\alpha \mathrm{q}$. Suppose that

$$
2 \alpha q>w\left(k_{t}^{1}\right)+w\left(k_{t}^{2}\right)
$$

holds for all t. Then the total demand for funds exceeds the total supply of funds, which is just $\mathrm{w}\left(\mathrm{k}_{\mathfrak{l}}^{1}\right)+\mathrm{w}\left(\mathrm{k}_{\mathrm{t}}^{2}\right)$. This situation is consistent with an equilibrium in credit markets if

$$
\mathrm{x}_{\mathrm{t}}^{\mathrm{i}}=\hat{\mathrm{x}}\left(\mathrm{b}_{\mathrm{t}}^{\mathrm{i}} / \rho_{\mathrm{t}+1}^{\mathrm{i}}\right) \equiv \hat{\mathrm{x}}\left\{\left[\mathrm{q}-\mathrm{w}\left(\mathrm{k}_{\mathrm{t}}^{\mathrm{i}}\right)\right] / \rho_{\mathrm{t}+1}^{\mathrm{i}}\right\} ; \quad \mathrm{i}=1,2
$$

holds for all t. This is true because, if (15) failed, it would be possible for (potential) borrowers who were denied external funding to obtain it by "bidding up" the interest rate that they offer. 
However, when (15) holds, "bidding up" the interest rate does not raise the expected return perceived by any potential lender, and hence does not attract any funds.

In short, if (A.4) and (15) hold at all dates, it is an equilibrium outcome for credit to be rationed in both countries. We focus on this case throughout.

\section{C1. Payoffs Under Credit Rationing}

From equation (11), the expected return to a lender at date t under a situation of credit rationing is given by

$$
\begin{aligned}
& \pi\left[\hat{\mathrm{x}}\left(\mathrm{b}_{\mathrm{t}}^{\mathrm{i} /} \rho_{\mathrm{t}+1}^{\mathrm{i}}\right) ;\left(\mathrm{b}_{\mathrm{t}}^{\mathrm{i} /} \rho_{\mathrm{t}+1}^{\mathrm{i}}\right)\right] \\
& \equiv \mathrm{q}\left(\rho_{\mathrm{t}+1}^{\mathrm{i}} / \mathrm{b}_{\mathrm{t}}^{\mathrm{i}}\right)\left\{\hat{\mathrm{x}}\left(\mathrm{b}_{\mathrm{t}}^{\mathrm{i} /} / \rho_{\mathrm{t}+1}^{\mathrm{i}}\right) \mathrm{b}_{\mathrm{t}}^{\mathrm{i}} / \mathrm{q} \rho_{\mathrm{t}+1}^{\mathrm{i}}-(\gamma / \mathrm{q}) \mathrm{G}\left[\hat{\mathrm{x}}\left(\mathrm{b}_{\mathrm{t}}^{\mathrm{i}} / \rho_{\mathrm{t}+1}^{\mathrm{i}}\right) \mathrm{b}_{\mathrm{t}}^{\mathrm{i}} / \mathrm{q} \rho_{\mathrm{t}+1}^{\mathrm{i}}\right]-\int_{0}^{\hat{x} \mathrm{~b}_{\mathrm{t}}^{\mathrm{i}} / \rho \rho_{t+1}^{\mathrm{i}}} \mathrm{G}(\mathrm{z}) \mathrm{dz}\right\} \\
& \equiv\left(\mathrm{q} \rho_{\mathrm{t}+1}^{\mathrm{i}} / \mathrm{b}_{\mathrm{t}}^{\mathrm{i}}\right)\left[\eta-(\gamma / \mathrm{q}) \mathrm{G}(\eta)-\int_{0}^{\eta} \mathrm{G}(\mathrm{z}) \mathrm{dz}\right] .
\end{aligned}
$$

Thus the lender's return on invested funds, $\mathrm{r}_{\mathrm{t}+1}$, depends only on $\rho_{\mathrm{t}+1}^{\mathrm{i}} / \mathrm{b}_{\mathrm{t}}^{\mathrm{i}}$ and parameters under credit rationing.

It is also easy to show that the expected utility of a borrower in country i (who obtains funds) under credit rationing is given by the expression

$$
\mathrm{q} \hat{\mathrm{z}} \rho_{\mathrm{t}+1}^{\mathrm{i}}-\mathrm{r}_{\mathrm{t}+1} \mathrm{~b}_{\mathrm{t}}^{\mathrm{i}}-\rho_{\mathrm{t}+1}^{\mathrm{i}} \gamma \mathrm{G}\left[\hat{\mathrm{x}}\left(\mathrm{b}_{\mathrm{t}}^{\mathrm{i} /} \rho_{\mathrm{t}+1}^{\mathrm{i}}\right) \mathrm{b}_{\mathrm{t}}^{\mathrm{i}} / \mathrm{q} \rho_{\mathrm{t}+1}^{\mathrm{i}}\right] \equiv \mathrm{q} \rho_{\mathrm{t}+1}^{\mathrm{i}}[\hat{\mathrm{z}}-(\gamma / \mathrm{q}) \mathrm{G}(\eta)]-\mathrm{r}_{\mathrm{t}+1} \mathrm{~b}_{\mathrm{t}}^{\mathrm{i}} .
$$

Any (potential) borrower, of course, always has the option of simply depositing his young period income in a bank, and obtaining the (expected) utility level $\mathrm{r}_{\mathrm{t}+1} \mathrm{w}_{\mathrm{t}}^{\mathrm{i}}$. Thus (potential) borrowers prefer borrowing to lending iff

$$
\mathrm{q} \rho_{\mathrm{t}+1}^{\mathrm{i}}[\hat{\mathrm{z}}-(\gamma / \mathrm{q}) \mathrm{G}(\eta)] \geq \mathrm{r}_{\mathrm{t}+1}\left(\mathrm{w}_{\mathrm{t}}^{\mathrm{i}}+\mathrm{b}_{\mathrm{t}}^{\mathrm{i}}\right)
$$


holds. Define the expected amount of capital produced, per unit invested and net of monitoring costs, by

$$
\phi \equiv \hat{z}-(\gamma / q) G(\eta)^{15}
$$

Then the definition of $\phi$-in conjunction with equation (3)-implies that (17) reduces to

$$
\phi \rho_{\mathrm{t}+1}^{\mathrm{i}} \geq \mathbf{r}_{\mathbf{t}+1} .
$$

If $\left(17^{\prime}\right)$ fails, borrowers will prefer not to borrow. Hence $\left(17^{\prime}\right)$ must be checked in our equilibrium derivations in what follows.

\section{General Equilibrium: The Closed Economy Case}

In this section we analyze the general equilibrium of either of the two countries as a closed economy: that is, we preclude international borrowing and lending. This will serve to highlight the role played by international credit markets in subsequent sections. Thus, for the present, we drop the superscripts denoting countries.

Let $\mu_{\mathrm{t}}$ denote the fraction of potential borrowers who actually obtain credit at $t$. Then the $\alpha\left(1-\mu_{t}\right)$ potential borrowers who are denied credit simply deposit their income with an intermediary. Equality between the supply and the "demand" for credit then requires that

$$
\alpha \mu_{\mathrm{t}}\left[\mathrm{q}-\mathrm{w}\left(\mathrm{k}_{\mathrm{t}}\right)\right]=(1-\alpha) \mathrm{w}\left(\mathrm{k}_{\mathrm{t}}\right)+\alpha\left(1-\mu_{\mathrm{t}}\right) \mathrm{w}\left(\mathrm{k}_{\mathrm{t}}\right) ; \quad \mathrm{t} \geq 0
$$

since each funded borrower obtains $\mathrm{b}_{\mathrm{t}} \equiv \mathrm{q}-\mathrm{w}\left(\mathrm{k}_{\mathrm{t}}\right)$ units of external funding. Equation (18) can be rewritten in the following more convenient form:

$$
\alpha \mu_{\mathrm{t}} \mathrm{q}=\mathrm{w}\left(\mathbf{k}_{\mathrm{t}}\right)
$$


Since capital investment returns are iid, and since there is a large number of borrowers, there is no aggregate randomness in this economy. Thus the time $t+1$ per capita capital stock is simply $\hat{z} \alpha q \mu_{\mathrm{t}}=\hat{z} \mathrm{w}\left(\mathrm{k}_{t}\right)$, less capital expended on monitoring at $\mathrm{t}+1$. The latter quantity is, of course, $\alpha \mu_{\mathrm{t}} \gamma \mathrm{G}\left[\mathrm{x}_{\mathrm{t}} \mathrm{b} / \mathrm{q} \rho_{\mathrm{t}+1}\right]=\gamma \mathrm{G}(\eta) \alpha \mu_{\mathrm{t}}$ under credit rationing. Therefore, the time $\mathrm{t}+1$ capital-labor ratio in final goods production obeys

$$
\mathrm{k}_{\mathrm{t}+1}=\hat{z} \mathrm{w}\left(\mathrm{k}_{\mathrm{t}}\right)-\alpha \mu_{\mathrm{t}} \gamma \mathrm{G}(\eta)
$$

Substituting (18 ) into (19), and using the definition of $\phi$ gives

$$
\mathrm{k}_{\mathrm{t}+1}=\phi \mathrm{w}\left(\mathrm{k}_{\mathrm{t}}\right) ; \quad \mathrm{t} \geq 0
$$

with $\mathrm{k}_{0}>0$ given. Equation (19') gives the equilibrium law of motion for the closed economy capital stock. $\left(19^{\prime}\right)$ describes a monotonic mapping between $k_{t}$ and $k_{t+1}$.

We now assume ${ }^{16}$

$$
\phi \mathrm{w}^{\prime}(0)>1
$$

Then, since $w^{\prime \prime}\left(k_{t}\right)<0$ (by assumption), the equilibrium law of motion given by $\left(19^{\prime}\right)$ looks as depicted in Figure 2. Clearly a unique nontrivial steady state capital stock, denoted by $\mathrm{k}^{*}$, exists and is unique. For any $k_{0}>0$, this steady state capital stock is approached monotonically. In order for credit rationing to obtain at this steady state, it is necessary that $\alpha q>w\left(k^{*}\right)$ hold. Then $\alpha \mathrm{q}>\mathrm{w}\left(\mathrm{k}_{\mathrm{t}}\right)$ holds for all $\mathrm{t} \geq 0$ if $\alpha \mathrm{q}>\max \left[\mathrm{w}\left(\mathrm{k}_{\mathrm{p}}\right)\right.$, $\left.\mathrm{w}\left(\mathrm{k}^{*}\right)\right]$.

In addition, it is necessary to check that $\left(17^{\prime}\right)$ holds. From (16),

$$
\mathrm{r}_{\mathrm{i}+1}=\left\{\mathrm{qf}^{\prime}\left(\mathrm{k}_{\mathrm{t}+1}\right) /\left[\mathrm{q}-\mathrm{w}\left(\mathrm{k}_{\mathrm{b}}\right)\right]\right\}\left[\eta-(\gamma / \mathrm{q}) \mathrm{G}(\eta)-\int_{0}^{\eta} \mathrm{G}(\mathrm{z}) \mathrm{dz}\right] .
$$

Then $\left(17^{\prime}\right)$ reduces to 


$$
\phi[\mathrm{q}-\mathrm{w}(\mathrm{k})] \geq \mathrm{q}\left[\eta-(\gamma / \mathrm{q}) \mathrm{G}(\eta)-\int_{0}^{\eta} \mathrm{G}(\mathrm{z}) \mathrm{dz}\right] ; \quad \mathrm{t} \geq 0
$$

It is easy to produce examples where (21) and $\alpha \mathrm{q}>\mathrm{w}\left(\mathrm{k}_{\mathrm{t}}\right)$ are satisfied at the steady state. For instance, the following example does so.

Example 1. Let $\mathrm{f}(\mathrm{k})=\mathrm{Ak}^{\beta}$, with $\beta \in(0,1)$, and let $\mathrm{g}(\mathrm{z}) \equiv 1 / \overline{\mathrm{z}}$. Then if $\mathrm{A}=1, \beta=0.5$, $\gamma=3 \mathrm{q} / 2$, and $\overline{\mathrm{z}}=2,(21)$ and $\alpha \mathrm{q}>\mathrm{w}\left(\mathrm{k}^{*}\right)$ hold if $\mathrm{q}>0.174$ and $\alpha>0.625$.

Discussion. If the two countries coexist as closed (noninteracting) economies, they will each converge to the nontrivial steady state from any positive initial capital stock. Thus output levels in the two countries must converge if the economies are closed.

Moreover, this convergence must be monotonic. Thus the credit market friction that we have analyzed is not a source of interesting dynamics in a closed economy.

\section{General Equilibrium: The Open Economy Case}

We now return to an examination of the situation where credit markets operate internationally, and hence we reintroduce country indices. As before, we continue to focus on the case where credit rationing is prevalent.

When intermediaries can borrow and lend internationally, the existence of an equilibrium in international financial markets requires that the expected returns offered by borrowers be the same in each country. Therefore, in equilibrium

$$
\pi\left[\hat{\mathrm{x}}\left(\mathrm{b}_{\mathrm{t}}^{1} / \rho_{\mathrm{t}+1}^{1}\right) ;\left(\mathrm{b}_{\mathrm{t}}^{1 / \rho_{\mathrm{t}+\mathrm{i}}^{1}}\right)\right]=\pi\left[\hat{\mathrm{x}}\left(\mathrm{b}_{\mathrm{t}}^{2} / \rho_{\mathrm{t}+1}^{2}\right) ;\left(\mathrm{b}_{\mathrm{t}}^{2} / \rho_{\mathrm{t}+1}^{2}\right)\right] ; \quad \mathrm{t} \geq 0
$$

must hold. From equation (16), this condition reduces to 


$$
\mathrm{f}^{\prime}\left(\mathrm{k}_{\mathrm{t}+1}^{1}\right) /\left[\mathrm{q}-\mathrm{w}\left(\mathrm{k}_{\mathrm{t}}^{1}\right)\right]=\mathrm{f}^{\prime}\left(\mathrm{k}_{\mathrm{t}+1}^{2}\right) /\left[\mathrm{q}-\mathrm{w}\left(\mathrm{k}_{\mathrm{t}}^{2}\right)\right] ; \quad \mathrm{t} \geq 0 .
$$

In addition, sources of funds and uses of funds must be equal in credit markets. Letting $\mu_{t}^{\mathrm{i}}$ be the fraction of potential borrowers who obtain credit in country $i$, borrowing and lending are equated internationally when

$$
\begin{aligned}
\alpha\left\{\mu_{\mathrm{t}}^{1}\left[\mathrm{q}-\mathrm{w}\left(\mathrm{k}_{\mathrm{t}}^{1}\right)\right]+\mu_{\mathrm{t}}^{2}\left[\mathrm{q}-\mathrm{w}\left(\mathrm{k}_{\mathrm{t}}^{2}\right)\right]\right\}= & (1-\alpha)\left[\mathrm{w}\left(\mathrm{k}_{\mathrm{t}}^{1}\right)+\mathrm{w}\left(\mathrm{k}_{\mathrm{t}}^{2}\right)\right]+\alpha\left(1-\mu_{\mathrm{t}}^{1}\right) \mathrm{w}\left(\mathrm{k}_{\mathrm{t}}^{1}\right) \\
& +\alpha\left(1-\mu_{\mathrm{t}}^{2}\right) \mathrm{w}\left(\mathrm{k}_{\mathrm{t}}^{2}\right) ; \quad \mathrm{t} \geq 0 .
\end{aligned}
$$

Upon rearranging terms, we may rewrite (23) as

$$
\alpha\left(\mu_{\mathrm{t}}^{1}+\mu_{\mathrm{t}}^{2}\right) \mathrm{q}=\mathrm{w}\left(\mathrm{k}_{\mathrm{t}}^{1}\right)+\mathrm{w}\left(\mathrm{k}_{\mathrm{t}}^{2}\right) ; \quad \mathrm{t} \geq 0 .
$$

As before, since there is no aggregate uncertainty, the time $t+1$ capital stock available for use in production (worldwide) is simply $\hat{z} \alpha\left(\mu_{t}^{1}+\mu_{t}^{2}\right) q=\hat{z}\left[w\left(k_{t}^{1}\right)+w\left(k_{t}^{2}\right)\right]$, less capital expended on monitoring. Total capital expenditures on state verification are $\alpha\left(\mu_{\mathrm{t}}^{1}+\mu_{\mathrm{t}}^{2}\right) \gamma \mathrm{G}(\eta)=$ $(\gamma / \mathrm{q}) \mathrm{G}(\eta)\left[\mathrm{w}\left(\mathrm{k}_{\mathrm{t}}^{1}\right)+\mathrm{w}\left(\mathrm{k}_{\mathrm{t}}^{2}\right)\right]$. Thus, in equilibrium

$$
\mathrm{k}_{\mathrm{t}+1}^{1}+\mathrm{k}_{\mathrm{t}+1}^{2}=[\hat{\mathrm{z}}-(\gamma / \mathrm{q}) \mathrm{G}(\eta)]\left[\mathrm{w}\left(\mathrm{k}_{\mathrm{t}}^{1}\right)+\mathrm{w}\left(\mathrm{k}_{\mathrm{t}}^{2}\right)\right] \equiv \phi\left[\mathrm{w}\left(\mathrm{k}_{\mathrm{t}}^{1}\right)+\mathrm{w}\left(\mathrm{k}_{\mathrm{t}}^{2}\right)\right] ; \quad \mathrm{t} \geq 0 .
$$

Equations (22') and (25) give the equilibrium law of motion governing the evolution of $\left\{\mathrm{k}_{\mathrm{t}}^{1}, \mathrm{k}_{\mathrm{t}}^{2}\right\}$.

Finally, in order to guarantee that credit is rationed in each country, as we have assumed, it is necessary that $\mu_{\mathrm{t}}^{\mathrm{i}}<1, \mathrm{i}=1,2$, holds for all t. This occurs iff

$$
\max \left(\mathrm{k}_{\mathrm{t}}^{1}, \mathrm{k}_{\mathrm{t}}^{2}\right)<\phi \alpha \mathrm{q}
$$

is satisfied for all $\mathrm{t} \geq 1$.

\section{A. Steady States}

Suppose we define the function $\mathrm{H}(\mathrm{k})$ by 


$$
\mathrm{H}(\mathrm{k}) \equiv \mathrm{f}^{\prime}(\mathrm{k}) /[\mathrm{q}-\mathrm{w}(\mathrm{k})]
$$

Then, by $\left(22^{\prime}\right)$, a steady state equilibrium must satisfy

$$
\mathrm{H}\left(\mathrm{k}^{1}\right)=\mathrm{H}\left(\mathrm{k}^{2}\right)
$$

where $\mathrm{k}^{\mathrm{i}}$ denotes the steady state capital-labor ratio in country i. In addition, (25) implies that $\mathrm{k}^{1}$ and $\mathrm{k}^{2}$ must satisfy

$$
\mathrm{k}^{1}+\mathrm{k}^{2}=\phi\left[\mathrm{w}\left(\mathrm{k}^{1}\right)+\mathrm{w}\left(\mathrm{k}^{2}\right)\right]
$$

Some properties of the function $\mathrm{H}$ will be important in the subsequent analysis. Therefore we now state

Lemma 1. The function $\mathrm{H}$ has the following properties:

$$
\begin{aligned}
& H(0)=\infty \\
& H(\hat{k})=\infty
\end{aligned}
$$

where $\hat{\mathrm{k}} \equiv \mathrm{w}^{-1}(\mathrm{q})$, and

$$
\begin{aligned}
& \leq 0 ; \quad \mathrm{k} \leq \mathrm{f}^{-1}(\mathrm{q}) \\
\mathrm{H}^{\prime}(\mathrm{k}) & \geq 0 ; \quad \mathrm{k} \geq \mathrm{f}^{-1}(\mathrm{q}) .
\end{aligned}
$$

Proof. Part (a) is immediate from the Inada conditions and $w(0)=0$. Part (b) is also immediate. For (c), straightforward differentiation yields

$$
H^{\prime}(k)=-[f(k)-q] f^{\prime \prime}(k) /[q-w(k)]^{2}
$$

giving the desired result. 
It follows from Lemma 1 that the function $\mathrm{H}(\mathrm{k})$ has the configuration depicted in Figure 3.

We now wish to derive-in Figure 4-the loci defined by equation (27). Evidently, whenever $k^{1}=k^{2}$, (27) is satisfied. Thus all points on the $45^{\circ}$ line in Figure 4 satisfy (27).

If $\mathrm{k}^{1}=\mathrm{f}^{-1}(\mathrm{q})$, evidently $\mathrm{k}^{2}=\mathrm{f}^{-1}(\mathrm{q})$ is the only value of $\mathrm{k}^{2}$ such that (27) holds. However, if $\mathrm{k}^{1}<\mathrm{f}^{-1}(\mathrm{q})$, there exists a (unique) value $\mathrm{k}^{2}>\mathrm{f}^{-1}(\mathrm{q})$ such that (27) is satisfied (see Figure 3). Similarly, if $k^{1}>f^{-1}(q)$, there exists a (unique) value $k^{2}<f^{-1}(q)$ such that (27) holds. Thus there exists a locus in Figure 4 -which intersects the $45^{\circ}$ line (only) at $\mathrm{k}^{1}=$ $\mathrm{f}^{-1}(\mathrm{q})$-along which (27) obtains. Evidently this locus is continuous and downward sloping. Finally, it intersects the horizontal axis at the point $(\hat{\mathrm{k}}, 0)$, and the vertical axis at the point $(0, \hat{\mathrm{k}}) \cdot{ }^{17}$

It now remains to trace out the locus defined by equation (28). To do so we note that (28) defines a continuous locus in Figure 4 that passes through each combination of closed economy steady states; that is, the combinations $\left(\mathrm{k}^{1}, \mathrm{k}^{2}\right)=\left(0, \mathrm{k}^{*}\right),\left(\mathrm{k}^{1}, \mathrm{k}^{2}\right)=\left(\mathrm{k}^{*}, 0\right)$, and $\left(\mathrm{k}^{1}, \mathrm{k}^{2}\right)=\left(\mathrm{k}^{*}, \mathrm{k}^{*}\right)$ clearly satisfy $(28) .{ }^{18}$ Thus the locus defined by $(28)$ intersects the $45^{\circ}$ line (only) at the point $\left(\mathrm{k}^{*}, \mathrm{k}^{*}\right)$. In addition, that locus has a slope given by the expression

$$
\mathrm{dk}^{2} /\left.\mathrm{dk}^{1}\right|_{(28)}=\left[\phi \mathrm{w}^{\prime}\left(\mathrm{k}^{\mathrm{l}}\right)-1\right] /\left[1-\phi \mathrm{w}^{\prime}\left(\mathrm{k}^{2}\right)\right]
$$

Therefore $\mathrm{dk}^{2} /\left.\mathrm{dk}^{1}\right|_{(28)}=-1$ holds at the point $\left(\mathrm{k}^{*}, \mathrm{k}^{*}\right)$.

Now define $\underline{k}$ by

$$
\phi \mathrm{w}^{\prime}(\underline{\mathrm{k}})=1 .
$$


Then evidently $\underline{\mathrm{k}}<\mathrm{k}^{*}$ (see Figure 2), and $\mathrm{dk}^{2} /\left.\mathrm{dk}^{1}\right|_{(28)} \geq 0$ holds iff $\left(\mathrm{k}^{1}, \mathrm{k}^{2}\right) \in[0, \underline{\mathrm{k}}] \times[\underline{\mathrm{k}}, \infty)$ or $\left(\mathrm{k}^{1}, \mathrm{k}^{2}\right) \in[\underline{\mathrm{k}}, \infty) \times[0, \underline{\mathrm{k}}]$. It follows that the locus defined by $(28)$ has the configuration depicted in Figure 4.

The next proposition is now immediate from an examination of Figure 4.

PROPosition 2. Suppose that $f\left(k^{*}\right)>q$, where $k^{*}$ is the nontrivial steady state capital-labor ratio of the closed economy. Then there exist at least three nontrivial steady states of the open economy (labeled points A, B, and C in Figure 4). All but one of these has $\mathbf{k}^{1} \not k \mathrm{k}^{2}$.

This proposition, of course, is subject to the following qualifications. Each of the candidate steady states must satisfy

$$
2 \alpha \mathrm{q}>\mathrm{w}\left(\mathrm{k}^{1}\right)+\mathrm{w}\left(\mathrm{k}^{2}\right)
$$

and $\max \left(\mathrm{k}^{1}, \mathrm{k}^{2}\right)<\phi \alpha \mathrm{q}$ in order for credit rationing to obtain, and must satisfy $\left(17^{\prime}\right)$ in order for (potential) borrowers to be willing to accept credit.

It is easy to produce examples with $f\left(k^{*}\right)>q$, and in which the candidate steady states with $\mathrm{k}^{1} \neq \mathrm{k}^{2}$ satisfy $\left(17^{\prime}\right),(30)$, and $\max \left(\mathrm{k}^{1}, \mathrm{k}^{2}\right)<\phi \alpha \mathrm{q}$. Here is one example which does so.

Example 2. Let $\mathrm{f}(\mathrm{k})=\mathrm{Ak}^{\beta}$, with $\mathrm{A}=0.85$, and $\beta=0.65$. Let $\alpha=0.7, \mathrm{q}=0.05$, and $\gamma=$ 0.0918 . Finally, let $g(z)=1 / \bar{z}$, with $\bar{z}=2$. Then $\phi=0.85$ holds, and it is possible to verify that there are exactly three nontrivial steady states. These have (a) $\mathrm{k}^{1}=\mathrm{k}^{2}=0.01968$, (b) $\mathrm{k}^{1}=0.02737, \mathrm{k}^{2}=0.004$, and (c) $\mathrm{k}^{1}=0.004, \mathrm{k}^{2}=0.02737$. All of these steady states satisfy $\left(17^{\prime}\right),(30)$, and $\max \left(\mathrm{k}^{1}, \mathrm{k}^{2}\right)<\phi \alpha \mathrm{q}$. 
We henceforth refer to steady states with $\mathrm{k}^{1}=\mathrm{k}^{2}$ as symmetric, and to steady states with $\mathbf{k}^{1} \neq \mathrm{k}^{2}$ as asymmetric. Since both equations (27) and (28) are symmetric, clearly asymmetric steady states come in pairs; that is, if $\left(\mathrm{k}^{1}, \mathrm{k}^{2}\right)$ is a steady state, so is $\left(\mathrm{k}^{2}, \mathrm{k}^{1}\right)$.

Discussion. What is the economics underlying the existence of asymmetric steady states? The answer to this question has to do with the presence of an informational friction in credit markets (the CSV problem), and with how this friction is affected by the ability of borrowers to provide some internal financing of their projects.

To fix ideas, consider an asymmetric steady state with $\mathrm{k}^{1}>\mathrm{k}^{2}$. In such an equilibrium, obviously, $\mathrm{f}^{\prime}\left(\mathrm{k}^{1}\right)<\mathrm{f}^{\prime}\left(\mathrm{k}^{2}\right)$, so that the marginal product of capital is highest in country 2 . In the absence of the CSV problem (or even in its presence if there was no ability to finance investment projects internally), this would render country 2 the attractive country to invest in, and this fact would preclude the existence of an asymmetric steady state. However, here potential borrowers can provide some internal financing of their projects, and their ability to finance internally depends on their young period income. Borrowers in country 1 have the young period income $w\left(k^{1}\right)>w\left(k^{2}\right)$; hence borrowers in country 1 have a superior ability to finance projects internally than do borrowers in country 2 . Since internal finance mitigates the CSV problem, this tends to counteract the attractiveness of country 2 as a home for investment, and in an asymmetric steady state these forces exactly balance one another. ${ }^{19}$

\section{B. Some Properties of Asymmetric Steady States}

In order to fix ideas, we consider asymmetric steady state equilibria with $\mathrm{k}^{1}>\mathrm{k}^{2}$. We first show that

PROPOSITION 3. In an asymmetric steady state with $\mathrm{k}^{1}>\mathrm{k}^{2}>0, \mathrm{k}^{1}>\mathrm{k}^{*}>\mathrm{k}^{2}$ holds. 
Proof. Suppose first that $\mathrm{k}^{*} \geq \mathrm{k}^{1}>\mathrm{k}^{2}$. Then, since $\mathrm{w}^{\prime \prime}(\mathrm{k})<0, \phi \mathrm{w}\left(\mathrm{k}^{1}\right) \geq \mathrm{k}^{1}$ and $\phi \mathrm{w}\left(\mathrm{k}^{2}\right)>$ $\mathrm{k}^{2}$ hold (see Figure 2). But this contradicts (28). A similar contradiction is derived if $\mathrm{k}^{1}>$ $\mathrm{k}^{2} \geq \mathrm{k}^{*}$

Proposition 3 asserts that, in any asymmetric steady state, one country finds itself wealthier than it would be in (any) symmetric steady state, and the other country finds itself poorer than it would be in the (nontrivial) symmetric steady state. Moreover, it is easy to show that the world capital stock is lower in any asymmetric steady state than in the symmetric steady state. More formally, we have

PROPOSITION 4. $\mathrm{k}^{1}+\mathrm{k}^{2}<2 \mathrm{k}^{*}$.

Proof. By definition, $\mathrm{k}^{1}+\mathrm{k}^{2}=2 \phi\left[\mathrm{w}\left(\mathrm{k}^{1}\right)+\mathrm{w}\left(\mathrm{k}^{2}\right)\right] / 2<2 \phi \mathrm{w}\left[\left(\mathrm{k}^{1}+\mathrm{k}^{2}\right) / 2\right]$, where the inequality follows from the strict concavity of $\mathrm{w}$. It is then immediate that $\left(\mathrm{k}^{1}+\mathrm{k}^{2}\right) / 2<\mathrm{k}^{*}$ (see Figure 2), establishing the proposition.

Thus not only is country 2 poorer in any asymmetric steady state than in the symmetric steady state, but so is the world economy.

In addition, it is also the case that, in any asymmetric steady state, the poor country is a net lender to the wealthier country. ${ }^{20}$ In other words, the net flow of funds for capital investment internationally in any asymmetric steady state is necessarily perverse. We state this as

PROPOSITION 5. $\mathrm{k}^{1}>\phi \mathrm{w}\left(\mathrm{k}^{1}\right)>\phi \mathrm{w}\left(\mathrm{k}^{2}\right)>\mathrm{k}^{2}$ holds in any asymmetric steady state equilibrium with $\mathrm{k}^{1}>\mathrm{k}^{2}>0$. 
Proof. This follows immediately from $\mathrm{k}^{1}>\mathrm{k}^{*}>\mathrm{k}^{2}$ and the strict concavity of $\mathrm{w}(\mathrm{k})$ (see Figure 2).

The fact that one country must be poorer in an asymmetric steady state than it would be under financial autarky (in which case it will approach the nontrivial symmetric steady state) raises the possibility that there will be pressures to reduce international borrowing and lending. We now briefly analyze who gains and who loses in a comparison of the (nontrivial) symmetric steady state with any asymmetric steady state.

Proposition 6. Suppose that $f\left(k^{*}\right)>q$ holds, and consider any asymmetric steady state with $\mathrm{k}^{1}>\mathrm{k}^{2}>0$. Lenders in country 1 prefer this equilibrium to the (nontrivial) symmetric steady state. Borrowers in country 1 (who obtain funds) prefer the (nontrivial) symmetric to the asymmetric steady state. For borrowers in country 2 (who obtain funds) the asymmetric steady state is preferred, while for lenders in country 2 the welfare ranking is ambiguous. Country 2 lenders prefer the symmetric to the asymmetric steady state if $w\left(k^{2}\right) \leq k^{2} f^{\prime}\left(k^{2}\right)$ holds. However, if $H\left(k^{2}\right)<1 / \phi q$, then this preference ranking is reversed.

Proof. The welfare of country 1 lenders in the asymmetric steady state is given by the expression

$$
\begin{aligned}
& \pi\left\{\hat{\mathrm{x}}\left(\left[\mathrm{q}-\mathrm{w}\left(\mathrm{k}^{1}\right)\right] / \mathrm{f}^{\prime}\left(\mathrm{k}^{1}\right)\right) ;\left[\mathrm{q}-\mathrm{w}\left(\mathrm{k}^{1}\right)\right] / \mathrm{f}^{\prime}\left(\mathrm{k}^{1}\right)\right\} \mathrm{w}\left(\mathrm{k}^{1}\right) \\
& \quad=\mathrm{H}\left(\mathrm{k}^{1}\right) \mathrm{w}\left(\mathrm{k}^{1}\right) \mathrm{q}\left[\eta-(\gamma / \mathrm{q}) \mathrm{G}(\eta)-\int_{0}^{\eta} \mathrm{G}(\mathrm{z}) \mathrm{dz}\right]
\end{aligned}
$$

where the second equality follows from (16) and the definition of $H$. The welfare of country 1 lenders in the symmetric steady state is given by $\mathrm{H}\left(\mathrm{k}^{*}\right) \mathrm{w}\left(\mathrm{k}^{*}\right) \mathrm{q}\left[\eta-(\gamma / \mathrm{q}) \mathrm{G}(\eta)-\int \eta \mathrm{G}(\mathrm{z}) \mathrm{dz}\right]$. 
Hence the welfare of country 1 lenders is higher in the asymmetric than in the symmetric steady state iff

$$
\mathrm{H}\left(\mathrm{k}^{1}\right) \mathrm{w}\left(\mathrm{k}^{1}\right)>\mathrm{H}\left(\mathrm{k}^{*}\right) \mathrm{w}\left(\mathrm{k}^{*}\right) .
$$

Clearly $w\left(k^{1}\right)>w\left(k^{*}\right)$ follows from $k^{1}>k^{*}$. Similarly, $H$ is increasing for all $k>f^{-1}(q)$. Hence, since $\mathrm{k}^{*}>\mathrm{f}^{-1}(\mathrm{q}), \mathrm{H}\left(\mathrm{k}^{1}\right)>\mathrm{H}\left(\mathrm{k}^{*}\right)$ also holds establishing (31).

For borrowers in country i who obtain funds, expected utility is given by the expression

$$
\begin{aligned}
\phi \mathrm{q} \rho_{\mathrm{t}+1}^{\mathrm{i}}-\mathrm{r}_{\mathrm{t}+1} \mathrm{~b}_{\mathrm{t}}^{\mathrm{i}} & =\phi \mathrm{q} \rho_{\mathrm{t}+1}^{\mathrm{i}}-\mathrm{r}_{\mathrm{t}+1}\left[\mathrm{q}-\mathrm{w}\left(\mathrm{k}^{\mathrm{i}}\right)\right] \\
& =\rho_{\mathrm{t}+1}^{\mathrm{i}}\left\{\phi \mathrm{q}-\mathrm{q}\left[\eta-(\gamma / \mathrm{q}) \mathrm{G}(\eta)-\int_{0}^{\eta} \mathrm{G}(\mathrm{z}) \mathrm{dz}\right]\right\}
\end{aligned}
$$

where the last line follows from $\mathrm{r}_{\mathrm{t}+1}=\pi\left[\hat{\mathrm{x}}\left(\mathrm{b}_{\mathrm{l}}^{\mathrm{i}} / \rho_{\mathrm{t}+1}^{\mathrm{i}}\right) ;\left(\mathrm{b}_{\mathrm{t}}^{\mathrm{i}} / \rho_{\mathrm{t}+1}^{\mathrm{i}}\right)\right]$ and (16). In the asymmetric steady state $\rho_{\mathrm{t}+1}^{1}=\mathrm{f}^{\prime}\left(\mathrm{k}^{1}\right)<\mathrm{f}^{\prime}\left(\mathrm{k}^{*}\right)$, so country 1 borrowers (who obtain funds) prefer the (nontrivial) symmetric steady state. An identical argument establishes the reverse welfare ranking for country 2 borrowers (who obtain funds).

Finally, country 2 lenders prefer the asymmetric to the (nontrivial) symmetric steady state iff $H\left(k^{2}\right) w\left(k^{2}\right)=H\left(k^{1}\right) w\left(k^{2}\right)>H\left(k^{*}\right) w\left(k^{*}\right)$ holds. We have established that $H\left(k^{1}\right)>H\left(k^{*}\right)$ and $\mathrm{w}\left(\mathrm{k}^{2}\right)<\mathrm{w}\left(\mathrm{k}^{*}\right)$; thus the welfare ranking of country 2 lenders is ambiguous.

Define $Q(k) \equiv H(k) w(k)$. It is straightforward to verify that

$$
\mathrm{kQ}^{\prime}(\mathrm{k}) / \mathrm{Q}(\mathrm{k})=\left[\mathrm{kw}^{\prime}(\mathrm{k}) / \mathrm{w}(\mathrm{k})\right]\left\{[\mathrm{q} /[\mathrm{q}-\mathrm{w}(\mathrm{k})]]-\mathrm{w}(\mathrm{k}) / \mathrm{kf}^{\prime}(\mathrm{k})\right\}
$$

Assumption (A.1) implies that $w(k) / k f^{\prime}(k)$ is decreasing in $k$, and clearly $q /[q-w(k)]>1$ holds for all $k>0$. Thus if $w\left(k^{2}\right) \leq k^{2} f^{\prime}\left(k^{2}\right)$ holds, $Q^{\prime}(k)>0$ is satisfied for all $k \geq k^{2}$. It follows that $\mathrm{H}\left(\mathrm{k}^{*}\right) \mathrm{w}\left(\mathrm{k}^{*}\right)>\mathrm{H}\left(\mathrm{k}^{2}\right) \mathrm{w}\left(\mathrm{k}^{2}\right)$. 
On the other hand, $\mathrm{Q}^{\prime}(\mathrm{k})<0$ holds iff $\mathrm{H}(\mathrm{k})<\mathrm{w}(\mathrm{k}) / \mathrm{qk}$. Again assumption (A.1) implies that $\mathrm{w}(\mathrm{k}) / \mathrm{k}$ is decreasing in $\mathrm{k}$ : therefore $\mathrm{w}(\mathrm{k}) / \mathrm{k} \leq \mathrm{w}\left(\mathrm{k}^{*}\right) / \mathrm{k}^{*}=1 / \phi$ holds for all $\mathrm{k} \leq$ $\mathrm{k}^{*}$. In addition, $\mathrm{H}(\mathrm{k}) \leq \mathrm{H}\left(\mathrm{k}^{2}\right)$ holds for all $\mathrm{k} \in\left[\mathrm{k}^{2}, \mathrm{k}^{*}\right]$. Thus a sufficient condition for $\mathrm{Q}^{\prime}(\mathrm{k})<0$ to hold, for all $\mathrm{k} \in\left[\mathrm{k}^{2}, \mathrm{k}^{*}\right]$, is that $\mathrm{H}\left(\mathrm{k}^{2}\right)<1 / \phi \mathrm{q}$. This condition guarantees that $\mathrm{H}\left(\mathrm{k}^{2}\right) \mathrm{w}\left(\mathrm{k}^{2}\right)>\mathrm{H}\left(\mathrm{k}^{*}\right) \mathrm{w}\left(\mathrm{k}^{*}\right)$.

Proposition 6 indicates that the political economy of closing financial markets is likely to be complex. ${ }^{21}$ It is possible that even though one country would be impoverished by being in an asymmetric steady state, it may still prefer that situation unambiguously to the symmetric steady state (if its lenders are made better off). The country that is wealthier in an asymmetric than in the symmetric steady state, however, may experience a conflict between borrowers and lenders about the desirability of open financial markets. Our current model, of course, has no implications for how such a conflict would be resolved.

\section{Local Dynamics}

We now turn our attention to the behavior of dynamical equilibria in the neighborhood of (symmetric or asymmetric) steady states. In order to make progress on this topic, we henceforth assume that both countries have Cobb-Douglas production functions; that is, we henceforth let $\mathbf{f}(\mathrm{k})=\mathrm{Ak}^{\beta} ; \beta \in(0,1)$.

The system of dynamical equilibrium conditions consists of equations $\left(22^{\prime}\right)$ and (25). Given the assumption of identical Cobb-Douglas technologies, these conditions assume the form

$$
\mathbf{k}_{\mathrm{t}+1}^{2} / \mathrm{k}_{\mathrm{t}+1}^{1}=\left\{\left[\mathrm{q}-(1-\beta) \mathrm{A}\left(\mathrm{k}_{\mathrm{t}}^{1}\right)^{\beta}\right] /\left[\mathrm{q}-(1-\beta) \mathrm{A}\left(\mathrm{k}_{\mathrm{t}}^{2}\right)^{\beta}\right]^{1 /(1-\beta)}\right.
$$

and

$$
\mathrm{k}_{\mathrm{t}+1}^{1}+\mathrm{k}_{\mathrm{t}+1}^{2}=\phi\left[(1-\beta) \mathrm{A}\left(\mathrm{k}_{\mathrm{t}}^{\mathrm{j}}\right)^{\beta}+(1-\beta) \mathrm{A}\left(\mathrm{k}_{\mathrm{t}}^{2}\right)^{\beta}\right]
$$


for all $t \geq 0$. It will now be convenient to proceed as follows. Define $y_{t} \equiv k_{t}^{2} / k_{t}^{1}$. Then (32) can be written as

$$
\mathrm{y}_{\mathrm{t}+1}=\left\{\left[\mathrm{q}-(1-\beta) \mathrm{A}\left(\mathrm{k}_{\mathrm{t}}^{1}\right)^{\beta}\right] /\left[\mathrm{q}-(1-\beta) \mathrm{A}\left(\mathrm{k}_{\mathrm{t}}^{1}\right)^{\beta} \mathrm{y}_{\mathrm{t}}^{\beta}\right]\right\}^{1 /(1-\beta)}
$$

while (33) becomes

$$
\begin{aligned}
\mathrm{k}_{\mathrm{t}+1}^{1} & =\phi(1-\beta) \mathrm{A}\left(\mathrm{k}_{\mathrm{t}}^{1}\right)^{\beta}\left(1+\mathrm{y}_{\mathrm{t}}^{\beta} / /\left(1+\mathrm{y}_{\mathrm{t}+1}\right)\right. \\
& =\phi(1-\beta) \mathrm{A}\left(\mathrm{k}_{\mathrm{t}}^{1}\right)^{\beta}\left(1+\mathrm{y}_{\mathrm{t}}^{\beta}\right) /\left\{1+\left\{\left[\mathrm{q}-(1-\beta) \mathrm{A}\left(\mathrm{k}_{\mathrm{t}}^{1}\right)^{\beta}\right] /\left[\mathrm{q}-(1-\beta) \mathrm{A}\left(\mathrm{k}_{\mathrm{t}}^{1}\right)^{\beta} \mathrm{y}_{\mathrm{t}}^{\beta}\right]\right\}^{1 /(1-\beta)}\right\}
\end{aligned}
$$

where the second equality in (35) follows from (34). Equations (34) and (35) constitute an alternative set of dynamical equilibrium conditions for this economy.

In order to analyze local dynamics, we next linearize the system (34) and (35) in a neighborhood of any steady state. Then we have

$$
\left(\mathrm{k}_{\mathrm{t}+1}^{1}-\mathrm{k}^{1}, \mathrm{y}_{\mathrm{t}+1}-\mathrm{y}\right)^{\prime}=\mathrm{J}\left(\mathrm{k}_{\mathrm{t}}^{1}-\mathrm{k}^{1}, \mathrm{y}_{\mathrm{t}}-\mathrm{y}\right)^{\prime}
$$

where $\mathrm{k}^{1}$ and $\mathrm{y}$ are steady state values, and $\mathrm{J}$ is the Jacobian matrix

$$
\mathbf{J}=\left[\begin{array}{ll}
\partial \mathrm{k}_{\mathrm{t}+1}^{1} / \partial \mathrm{k}_{\mathrm{t}}^{1} & \partial \mathrm{k}_{\mathrm{t}+1}^{1} / \partial \mathrm{y}_{\mathrm{t}} \\
\partial \mathrm{y}_{\mathrm{t}+1} / \partial \mathrm{k}_{\mathrm{t}}^{1} & \partial \mathrm{y}_{\mathrm{t}+1} / \partial \mathrm{y}_{\mathrm{t}}
\end{array}\right]
$$

with partial derivatives evaluated at the appropriate steady state.

The relevant expressions for the partial derivatives evaluated at any steady state are as follows:

$$
\begin{aligned}
& \partial \mathrm{k}_{\mathrm{t}+1}^{1} / \partial \mathrm{k}_{\mathrm{t}}^{1}=\beta+\beta \mathrm{q}\left(1-\mathrm{y}^{\beta}\right) \mathrm{f}\left(\mathrm{yk}^{1}\right) /(1+\mathrm{y})\left[\mathrm{q}-(1-\beta) \mathrm{f}\left(\mathrm{yk}^{1}\right)\right]^{2} \\
& \partial \mathrm{k}_{\mathrm{t}+1}^{1} / \partial \mathrm{y}_{\mathrm{t}}=\left(\mathrm{k}^{1} / \mathrm{y}\right) \beta \mathrm{y}^{\beta} /\left(1+\mathrm{y}^{\beta}\right)-\left(\mathrm{k}^{1} / \mathrm{y}\right) \beta \mathrm{f}\left(\mathrm{k}^{1} \mathrm{y}\right) \mathrm{y} /(1+\mathrm{y})\left[\mathrm{q}-(1-\beta) \mathrm{f}\left(\mathrm{yk}^{1}\right)\right] \\
& \partial \mathrm{y}_{\mathrm{t}+1} / \partial \mathrm{k}_{\mathrm{t}}^{1}=\left(\mathrm{y} / \mathrm{k}^{1}\right) \beta \mathrm{f}\left(\mathrm{yk}^{1}\right) /\left[\mathrm{q}-(1-\beta) \mathrm{f}\left(\mathrm{yk}^{1}\right)\right]-\left(\mathrm{y} / \mathrm{k}^{1}\right) \beta \mathrm{f}\left(\mathrm{k}^{1}\right) /\left[\mathrm{q}-(1-\beta) \mathrm{f}\left(\mathrm{k}^{1}\right)\right] \\
& \partial \mathrm{y}_{\mathrm{t}+1} / \partial \mathrm{y}_{\mathrm{t}}=\beta \mathrm{f}\left(\mathrm{yk}^{1}\right) /\left[\mathrm{q}-(1-\beta) \mathrm{f}\left(\mathrm{yk}^{1}\right)\right] .
\end{aligned}
$$


For future reference, let $\mathrm{T}$ denote the trace of $\mathrm{J}$ and let $\mathrm{D}$ denote its determinant, and we let $\lambda_{1}$ and $\lambda_{2}$ denote the eigenvalues of $\mathrm{J}$.

\section{A. Dynamics in a Neighborhood of the Symmetric Steady State}

The (nontrivial) symmetric steady state has $y=1$ and $k^{1}=k^{*}$. It follows from (39) that $\partial \mathrm{y}_{\mathrm{t}+1} / \partial \mathrm{k}_{\mathrm{t}}^{1}=0$ at this steady state, and therefore that the eigenvalues of $\mathrm{J}$ are given by $\lambda_{\mathrm{l}}=$ $\partial \mathrm{k}_{\mathrm{t}+1}^{1} / \partial \mathrm{k}_{\mathrm{t}}^{1}$ and $\lambda_{2}=\partial \mathrm{y}_{\mathrm{t}+1} / \partial \mathrm{y}_{\mathrm{t}}$. Moreover, it is clear from (37) that $\mathrm{y}=1$ implies that $\partial \mathrm{k}_{\mathrm{t}+1}^{1} / \partial \mathrm{k}_{\mathrm{t}}^{1}=\beta \in(0,1)$. Equation (40) implies that $\partial \mathrm{y}_{\mathrm{t}+\mathrm{1}} / \partial \mathrm{y}_{\mathrm{t}}=\beta \mathrm{f}\left(\mathrm{k}^{*}\right) /\left[\mathrm{q}-(1-\beta) \mathrm{f}\left(\mathrm{k}^{*}\right)\right]$ at this steady state. We now state

PROPOSITION 7. Suppose that $f\left(k^{*}\right)>q$. Then $\partial y_{t+1} / \partial y_{t}>1$ at the symmetric steady state.

Proof. That $\partial \mathrm{y}_{\mathrm{t}+1} / \partial \mathrm{y}_{\mathrm{t}}>0$ follows from the fact that, at the symmetric steady state, $(1-\beta) \mathrm{f}\left(\mathrm{k}^{*}\right) \equiv \mathrm{w}\left(\mathrm{k}^{*}\right)<\mathrm{q}$.

Now suppose, for the purpose of proof by contradiction, that $\partial \mathrm{y}_{t+1} / \partial \mathrm{y}_{\mathrm{t}} \leq 1$. This is equivalent to the assertion that $\beta \mathrm{f}\left(\mathrm{k}^{*}\right) \leq \mathrm{q}-(1-\beta) \mathrm{f}\left(\mathrm{k}^{*}\right)$, implying that $\mathrm{q} \geq \mathrm{f}\left(\mathrm{k}^{*}\right)$. But this is the desired contradiction.

The condition $f\left(k^{*}\right)>q$ is sufficient for the existence of asymmetric steady states, as shown in Section 4. The same condition that implies their existence also implies that $\partial \mathrm{y}_{t+1} / \partial \mathrm{y}_{\mathrm{t}}>1$, and hence that the symmetric steady state is a saddle. Moreover, the saddle path is particularly simple: it is $y_{t}=1$. Since equation (34) implies that if $y_{t} \neq 1, y_{t+1} \neq 1$ holds as well, it is apparent that economies with different initial capital stocks cannot converge to the same (nontrivial) capital-labor ratios or output levels. This is true even though the economies must converge to the same capital-labor ratios and output levels if they are closed. 
This same result also implies that, for economies that differ with respect to their initial capital stocks, it is the asymmetric steady states that are of interest. We now comment on the properties of dynamical equilibria near an asymmetric steady state.

\section{B. Dynamics in a Neighborhood of an Asymmetric Steady State}

For any asymmetric steady state, it is straightforward but tedious to establish the following relationships:

$$
\mathrm{D}=\beta\left[\left(1+\mathrm{y}^{\beta-1}\right) /\left(1+\mathrm{y}^{\beta}\right)\right] \beta \mathrm{f}\left(\mathrm{yk}^{1}\right) /\left[\mathrm{q}-(1-\beta) \mathrm{f}^{\left.\left(\mathrm{yk}^{1}\right)\right]>0}\right.
$$

and

$$
\mathrm{T}=\beta+2 \beta \mathrm{f}\left(\mathrm{yk}^{1}\right) /(1+\mathrm{y})\left[\mathrm{q}-(1-\beta) \mathrm{f}^{\left.\left(\mathrm{yk}^{1}\right)\right]}>0\right.
$$

where the inequalities follow from $(1-\beta) f\left(\mathrm{yk}^{1}\right)=(1-\beta) \mathrm{f}\left(\mathrm{k}^{2}\right)=\mathrm{w}\left(\mathrm{k}^{2}\right)<\mathrm{q}$. Thus $\lambda_{1}$ and $\lambda_{2}$ are either both positive real numbers, or are complex conjugates.

We have not succeeded in providing a general characterization of the local stability properties of asymmetric steady states. However, we have established the following result yielding sufficient conditions for any asymmetric steady state to be a sink.

Proposition 8. Consider an asymmetric steady state with $y<1$. (a) If

$$
\mathrm{y}^{\beta}\left(1+\mathrm{y}^{\beta-1}\right) /\left(1+\mathrm{y}^{\beta}\right) \leq \mathrm{f}^{-1}(\mathrm{q}) / \mathrm{q} \phi \alpha
$$

holds, then $\mathrm{D}<\beta$ and $\mathrm{T}<1+\mathrm{D}$ are satisfied. (b) Equation (43) holds if $\beta \geq 0.5$ and $\mathrm{f}^{-1}(\mathrm{q}) / \mathrm{q} \phi \alpha \geq 1$. 
The proof is available from the authors on request. Proposition 8 gives sufficient conditions for $\mathrm{D}<1$ and $\mathrm{T}<1+\mathrm{D}$ to hold. These conditions are sufficient to guarantee that an asymmetric steady state is a sink.

The conditions stated in proposition 8 are much stronger than will typically be needed to imply the local stability of an asymmetric steady state. We have calculated a large number of numerical examples satisfying our maintained hypotheses, and all of which have two asymmetric steady states. For all of the examples, the asymmetric steady states are sinks. We now report two representative examples. For both of them, equation (43) is violated.

Example 3. The economy is identical to that of Example 2. The eigenvalues of $\mathrm{J}$, evaluated at the steady state with $\mathrm{k}^{1}=0.02737, \mathrm{y}=\mathrm{k}^{2} / \mathrm{k}^{1}=0.146$, are $0.6436 \pm(0.3633) \mathrm{i}$. Thus this steady state is a sink, and paths approaching it display damped oscillation.

Indeed, we found a variety of parameter values for which the asymmetric steady states are sinks, and for which $\lambda_{1}$ and $\lambda_{2}$ are complex conjugates. However, locally monotone dynamics are also possible, as the next example indicates.

Example 4. This example has $\mathrm{A}=0.7, \beta=0.25, \mathrm{q}=0.5, \alpha=0.925$, and $\gamma=0.8162$. In addition, $\mathrm{g}(\mathrm{z})=1 / \overline{\mathrm{z}}$, with $\overrightarrow{\mathrm{z}}=2$. This implies that $\phi=0.7$. There are three steady states: (a) one with $\mathrm{y}=1$, (b) one with $\mathrm{y}=0.69$, and $\mathrm{k}^{1}=0.31$, and (c) one with $\mathrm{y}=1.44=$ $0.69^{-1}$, and $\mathrm{k}^{1}=0.214$. The eigenvalues associated with the second steady state are $\lambda_{1}=$ 0.9772 and $\lambda_{2}=0.2588$. Hence paths approaching the asymmetric steady state are locally monotonic. ${ }^{22}$

We now illustrate some nonlocal dynamical behavior for the economy of Example 3. Figure 5 displays the time path of the relative capital stocks $\left(\left\{y_{t}\right\}\right)$ for the two economies if $y_{0}=$ 
$\mathrm{k}_{0}^{2} / \mathrm{k}_{0}^{1}=0.146$, and if $\mathrm{k}_{0}^{1}=0.028$. Notice that the initial relative capital stocks of the two economies equal their steady state values. Nevertheless, as Figure 5 indicates, the relative position of the poor economy undergoes fairly dramatic variation over time, even though no asymptotic adjustment is required. Of course, the fluctuations experienced by country 2 are necessarily accompanied by substantial net inflows and outflows of foreign investment as the steady state is approached.

As Figure 5 illustrates, even though economy 2 will asymptotically do poorly, relatively speaking, it can experience several generations of rapid growth relative to economy 1. However, this growth cannot be sustained in the face of the wealthy economy's superior ability to provide internal financing of investment projects. In addition, dynamical equilibrium paths can easily display damped oscillation. Thus credit market imperfections, coupled with international borrowing and lending, are potentially a source of endogenous fluctuations. Both features are required for such fluctuations to be observed: no endogenous fluctuations can occur in the closed economy version of the model with a CSV problem in credit markets, nor can such fluctuations occur in an open economy version of the model in the absence of the CSV problem.

\section{Conclusion}

We have examined an open economy model where capital investments must be financed, in part, by credit extension. The allocation of credit is affected by a CSV problem; the severity of this problem depends on the ability of borrowers to provide internal financing of their projects. In countries with high capital stocks (and income levels), more internal financing will be provided than is the case in countries with low capital stocks. As a result, countries with relatively high capital stocks will be attractive places to invest, and such countries will be net 
recipients of external capital investment. This allows them to maintain (permanently) their relative positions. By implication, currently poor countries will also be made permanently poor by the operation of international financial markets.

While, as demonstrated in Section 5, this observation has no necessary implications for welfare, it is suggestive of why many developing countries are not interested in opening their financial markets to the rest of the world. Moreover, the operation of international credit markets can be a source of enhanced economic volatility, which no doubt contributes to the reluctance of many countries to allow the unimpeded operation of international credit allocation.

Admittedly these results depend on several strong assumptions. One that deserves comment is that, by construction, credit rationing always prevails in the world we have considered. This construction appears to be necessary for tractability, but we also believe that it is not an unrealistic assumption. Even in the United States credit rationing is deemed to be important, as indicated by the array of government policies intended to aid its "victims." In developing countries, credit rationing is even more significant, and policy interventions motivated by its presence are even more sweeping. ${ }^{23}$ And there is substantial empirical evidence of widespread credit rationing, even in the United States [21].

A second comment is that the credit rationing that arises here is due solely to the presence of the CSV problem, which may be thought to be of limited practical significance. However, it should be possible to introduce other informational frictions as well, as we have done elsewhere [4], [5], and to obtain similar results.

Third, our results have been obtained in the context of an economy that has a steady state equilibrium. Environments that can display permanent growth would be problematic in the model we have considered, which has an upper bound on total investment capacity, and which 
has a fixed verification cost which would become negligible as an economy grows without limit. We conjecture that-by allowing investment capacity and verification costs to grow with the rest of the economy-our results can be extended to models that can display permanent growth.

There are, of course, a number of extensions of the analysis that could potentially be undertaken. One would be to alter the model in a way that would allow "borrowers" in each country to issue, in equilibrium, a larger set of potential claims to foreigners than they do here. In particular, while in principal our model allows capital flows to take the form of foreign direct investment or portfolio equity, it is suboptimal for external financing to take these forms so, for instance, the equilibrium quantity of foreign direct investment is zero. By extending the set of investment opportunities available to borrowers to include some with freely observable returns, as in [7] and [8], it is possible to have investors issuing a larger set of liabilities, including equity claims, than they do here. Allowing this to take place in international capital markets would constitute an interesting extension of the current model. ${ }^{24}$

Another interesting extension would be to allow for more heterogeneity among borrowers. One possibility would be to allow borrowers to operate at different scales so that, loosely speaking, there would be a distribution of q's in the population of each country. Another would be to allow borrowers to differ with respect to their ability to provide internal finance. This would provide a richer theory of why certain borrowers are rationed since, under our assumptions, agents who can operate at a larger scale or who can provide more internal financing are more attractive as recipients of external funding. A model with these features would also give rise to an endogenously derived income distribution in each country, and this income distribution would typically matter for the level of real activity. 
Finally, as we have already mentioned, a number of countries engage in large scale interventions in financial markets in order to affect the allocation of credit domestically. ${ }^{25} \mathrm{~A}$ natural topic for further investigation would concern the consequences of such policies for the issues we have analyzed. It would also be possible to investigate the operation of the economy when credit rationing exists in only one (or in neither) country. At this point, however, all of these must remain open issues. 


\section{Footnotes}

${ }^{1}$ According to [35, Table 21], 28 of the 40 low income countries in the World Bank sample report private, nonguaranteed external (long-term) debt levels of zero.

${ }^{2}$ Again relying on $[35$, p. 131$]$, "many developing countries continue to restrict outward capital flows in an attempt to direct more domestic funds to domestic investment." This is true even of relative growth successes, like Korea and Taiwan. Until very recently, Korea restricted external asset holdings by domestic residents as well as the amount of debt or equity of domestic firms that could be held abroad. And, according to [13, p. 375], "until July of 1987 . the [Taiwanese] economy was functionally closed financially."

${ }^{3}$ Both the Wall Street Journal of January 30, 1995 (p. 1) and the Economist of February 4, 1995 (p. 72) argue for the desirability of restrictions on capital inflows to developing countries. See the second reference for some description of Chilean restrictions on capital inflows.

${ }^{4}$ In particular, in the model we analyze, all goods trade will be a consequence of financial market activity.

${ }^{5}$ This does not imply that the international balance of payments favors the poor country. Whether it does or not depends on whether or not the equilibrium world interest rate exceeds the rate of population growth.

${ }^{6}$ Considerable empirical evidence, for example, [9], [11], and [16], finds that exogenous factors do little to explain capital flows, or changes in them, to developing countries. This suggests the potential value of identifying endogenous factors that contribute to volatility in these flows.

${ }^{7}$ Gertler and Rogoff [18] consider an economy in which the ability to provide internal investment finance mitigates a moral hazard problem. However, in their model, the quantity of internal finance provided is a purely exogenous variable that is uninfluenced by investment activity. Their paper is therefore not geared to address how the ability of an economy's investors to provide 
partial internal financing will (or even might) evolve over time, or respond to endogenous factors. This is the essential feature of our analysis.

It is also the case that Gertler and Rogoff's model does not necessarily yield the result that private funds will flow from poor to rich economies, although this can occur-particularly if the government of the poor country has a sufficiently large external debt. Here, on the other hand, the allocation of credit must be perverse in an asymmetric steady state. This result does not require any particular policy intervention.

${ }^{8}$ That is, in verifying the project return $\gamma$ units of capital are used up. This specification of the verification cost follows [2].

The assumption that state verification uses only capital substantially simplifies the analysis and, in particular, is responsible for the very simple form taken by the expected return function under credit rationing [see equation (16)]. However, the assumption that state verification consumes capital rather than labor also allows us to avoid a rather implausible implication. In particular, if the state verification technologies were identical across countries, and if state verification consumed labor, monitoring would be cheaper in the poorer country because of its lower wage rate. The notion that credit market frictions are intrinsically less severe in poorer countries is wildly at variance with observation. On the latter point see [35].

${ }^{9}$ That is, $f\left(k_{l}^{i}\right) \equiv F\left(k_{l}^{i}, 1\right)$. Notice that, under our assumptions, $f(0)=0$ holds.

${ }^{10}$ Assumption (A.1) implies the existence of at most one nontrivial steady state when each country is autarkic (see Section 4). As such, it is a standard assumption made to guarantee uniqueness in the Diamond [14] model with constant savings rates. On the latter point see, for instance, the discussion in [1].

${ }^{11}$ Notice that we do not allow for stochastic monitoring. While this is a real restriction, [6] shows that the gains to stochastic monitoring are trivial for realistic parameter values. 
${ }^{12}$ Since funds are mobile between countries, this must be the same in each location.

${ }^{13}$ Notice that we assume, without loss of generality that verification costs are born by lenders.

${ }^{14}$ This assumption is standard in CSV models focusing on credit rationing. See, for instance, [33] and [34].

${ }^{15}$ Clearly we will assume throughout that $\phi>0$.

${ }^{16}$ Assumption (A.5) is a standard condition required to guarantee the existence of a nontrivial steady state equilibrium in the Diamond model when savings rates are constant (as they are here) and when $f(0)=0$. (See, for instance, [1].) (A.5) is satisfied, for example, by any CES production function with an elasticity of substitution no less than one.

${ }^{17}$ It should also be apparent that this locus is symmetric about the $45^{\circ}$ line. Also, since we have assumed that $\mathrm{w}\left(\mathrm{k}^{*}\right)<\mathrm{q}$, it follows that $\hat{\mathrm{k}} \equiv \mathrm{w}^{-1}(\mathrm{q})>\mathrm{k}^{*}$.

${ }^{18}$ So does the combination $\left(\mathrm{k}^{1}, \mathrm{k}^{2}\right)=(0,0)$, but we have no interest in this (trivial) steady state equilibrium.

${ }^{19}$ The importance of internal finance in CSV models is the theme of Bernanke and Gertier [2]. That this theme extends to other kinds of models displaying informational asymmetries is indicated by Gertler and Rogoff [18]. In their model, however, the quantity of internal finance provided by investors is a purely exogenous variable.

We should note that formally we have only demonstrated that internal finance works in this way when monitoring consumes capital.

${ }^{20}$ The fact that the wealthy economy is a net debtor implies that it makes net interest payments to the poor country. While these interest payments reduce the income differences between the economies in an asymmetric steady state, they do not eliminate them. For example, in the situation illustrated by example $2, f\left(k^{1}\right)=0.08197$ and $f\left(k^{2}\right)=0.02564$. Net interest payments from country 
1 to country 2 in the asymmetric steady state are 0.00012 . Thus these make almost no difference to the international distribution of income.

${ }^{21}$ Of course proposition 5 considers only a comparison of steady states. Matters are likely to be even more complex when transitional dynamics are taken into account.

${ }^{22}$ It is easy to verify that all the steady states of this economy satisfy $2 \alpha q>w\left(k^{1}\right)+w\left(k^{2}\right)$, $\left(17^{\prime}\right)$, and $\max \left(\mathrm{k}^{1}, \mathrm{k}^{2}\right)<\phi \alpha \mathrm{q}$. In addition, $\mathrm{f}\left(\mathrm{k}^{1}\right)=0.5223$ and $\mathrm{f}\left(\mathrm{k}^{2}\right)=0.4761$ hold in the second steady state. Net interest payments from county 1 to country 2 are 0.0034 , so that again interest payments scarcely affect the international distribution of income.

${ }^{23}$ For a discussion of informational frictions that lead to credit rationing in developing countries see [3], [15], [23], [24], and [26]. For a discussion of government programs motivated by this rationing see [3], [10], and [24]. For a discussion of some such programs in the United States, see [29].

${ }^{24}$ As an empirical matter, the fact that foreign direct investment has no role to play in our model does not seem like a particularly significant omission. From 1976 through 1992, foreign direct investment accounted for only 1.8 percent of total capital flows in Argentina, -1.0 percent in Brazil, 2.1 percent in Germany, 0.7 percent in Indonesia, 2.8 percent in Korea, and -1.3 percent in Mexico. Even in Japan, foreign direct investment over this period accounted for only 5.9 percent of total capital flows. For further details, see [12].

${ }^{25}$ See [22], [31], or [32] for a discussion of some such policies. 


\section{References}

1. C. Azariadis, "Intertemporal Macroeconomics," Basil Blackwell, London, 1992.

2. B. S. Bernanke, and M. Gertler, Agency costs, net worth, and business fluctuations, Amer. Econ. Rev. 79 (1989), 14-31.

3. V. V. Bhatt, On financial innovation and credit market evolution, World Devel. 16 (1988), $281-292$.

4. J. H. Boyd, and B. D. Smith, Intermediation and the equilibrium allocation of investment capital: Implications for economic development, J. Monet. Econ. 30 (1992), 409-432.

5. , The equilibrium allocation of investment capital in the presence of adverse selection and costly state verification, Econ. Theory 3 (1993), 427-451.

6. , The welfare costs of absolute priority: Stochastic versus nonstochastic monitoring in a costly state verification environment, J. Bus., 1994a.

7. , The use of debt and equity in optimal financial contracts, manuscript, Federal Reserve Bank of Minneapolis, 1994b.

8. ___ The evolution of debt and equity markets in economic development, manuscript, Federal Reserve Bank of Minneapolis, 1994c.

9. G. Calvo, L. Leiderman, and C. Reinhart, Capital inflows and the real exchange rate appreciation in Latin America: The role of external factors, IMF Staff Pap. 40 (1993), $108-151$.

10. A. G. Chandavarkar, Some aspects of interest rate policies in less-developed economies: The experience of selected Asian countries, IMF Staff Pap. 18 (1971), 48-111. 
11. P. Chuhan, S. Claessens, and N. Mamingi, Equity and bond flows to Latin American and Asia: The role of global and country factors, manuscript, World Bank, 1993.

12. S. Claessens, M. P. Dooley, and A. Warner, Portfolio capital flows: Hot or cold?, World Bank Econ. Rev. 9 (1995), 153-174.

13. T. J. Cunningham, Some evidence on the real-bills doctrine versus the quantity theory, Econ. Inquiry 30 (1992), 371-383.

14. P. A. Diamond, National debt in a neoclassical growth model, Amer. Econ. Rev. 55 (1965), 1126-1150.

15. C. Diaz-Alejandro, Good-bye financial repression, hello financial crash, J. Devel. Econ. 19 (1985), 1-24.

16. E. Fernandez-Arias, The new wave of private capital flows: Push or pull?, manuscript, World Bank, 1994.

17. D. Gale, and M. Hellwig, Incentive-compatible debt contracts: The one-period problem, Rev. of Econ. Stud. 52 (1985), 647-663.

18. M. Gertler, and K. Rogoff, North-South lending and endogenous domestic capital market inefficiencies, J. Monet. Econ. 26 (1990), 245-266.

19. J. Greenwood, and B. Jovanovic, Financial development, growth, and the distribution of income, J. Polit. Econ. 98 (1990), 1076-.

20. United Nations, "Human Development Report 1992," Oxford University Press, New York, (1992).

21. T. Jappelli, Who is credit constrained in the U.S. economy? Quart. J. Econ. 105 (1990), 219-234. 
22. F. Jaramillo, F. Schiantarelli, and A. Weiss, The effect of financial liberalization on the allocation of credit: Panel data evidence for Ecuador, manuscript, World Bank, 1992.

23. D. Khatkate, National and international aspects of financial policy in LDCs: A prologue, World Devel. 10 (1982a), 689-694.

24. , Anatomy of financial retardation in a less developed country: The case of Sri Lanka, 1951-1976, World Devel. 10 (1982b), 829-840.

25. C. H. Ma, and B. D. Smith, Credit market imperfections and economic development: Theory and evidence, J. Devel. Econ, forthcoming.

26. R. I. McKinnon, "Money and Capital in Economic Development," Brookings Institute, Washington, DC, 1973.

27. S. L. Parente, and E. C. Prescott, Changes in the wealth of nations, Federal Reserve Bank of Minneapolis Quart. Rev, 17 (1993), 3-16.

28. A. Singh, and J. Hamid, Corporate financial structures in developing countries. Technical Paper 1, World Bank, 1993.

29. B. D. Smith, and M. J. Stutzer, Credit rationing and government loan programs: A welfare analysis, Amer. Real Estate and Urban Econ. Assoc. J. 17 (1989), 177-193.

30. R. M. Townsend, Optimal contracts and competitive markets with costly state verification, J. Econ. Theory 21 (1979), 265-293.

31. J. R. Tybout, Credit rationing and investment behavior in a developing country, Rev. Econ. Stat. 65 (1983), 598-607.

32. , Interest controls and credit allocation in developing countries, J. Money, Credit, and Banking 16 (1984), 474-487. 
33. S. D. Williamson, Costly monitoring, financial intermediation, and equilibrium credit rationing, J. Monet. Econ. 18 (1986), 159-179.

34. Costly monitoring, loan contracts, and equilibrium credit rationing, Quart. J. Econ. 102 (1987), 135-145.

35. World Bank, "World Development Report 1989," Oxford University Press, New York, 1989. 
Table I

Net Financial Transfers on Long-Term

Lending to Developing Countries

\begin{tabular}{cc}
\hline \hline Year & $\begin{array}{c}\text { Amount } \\
\text { (US \$, bils.) }\end{array}$ \\
\hline 1972 & 7.1 \\
1973 & 10.8 \\
1974 & 16.7 \\
1975 & - \\
1976 & 21.5 \\
1977 & 25.0 \\
1978 & 33.2 \\
1979 & 31.2 \\
1980 & 29.5 \\
1981 & 35.9 \\
1982 & 20.1 \\
1983 & 3.7 \\
1984 & -10.2 \\
1985 & -20.5 \\
1986 & -23.6 \\
1987 & -34.0 \\
1988 & -35.2 \\
1989 & -29.6 \\
1990 & -22.5 \\
\hline \hline
\end{tabular}

Source: Human Development Report 1992, Table 4-3 (p.50) 
Figure 1.

\section{THE EXPECTED RETURN FUNCTION}

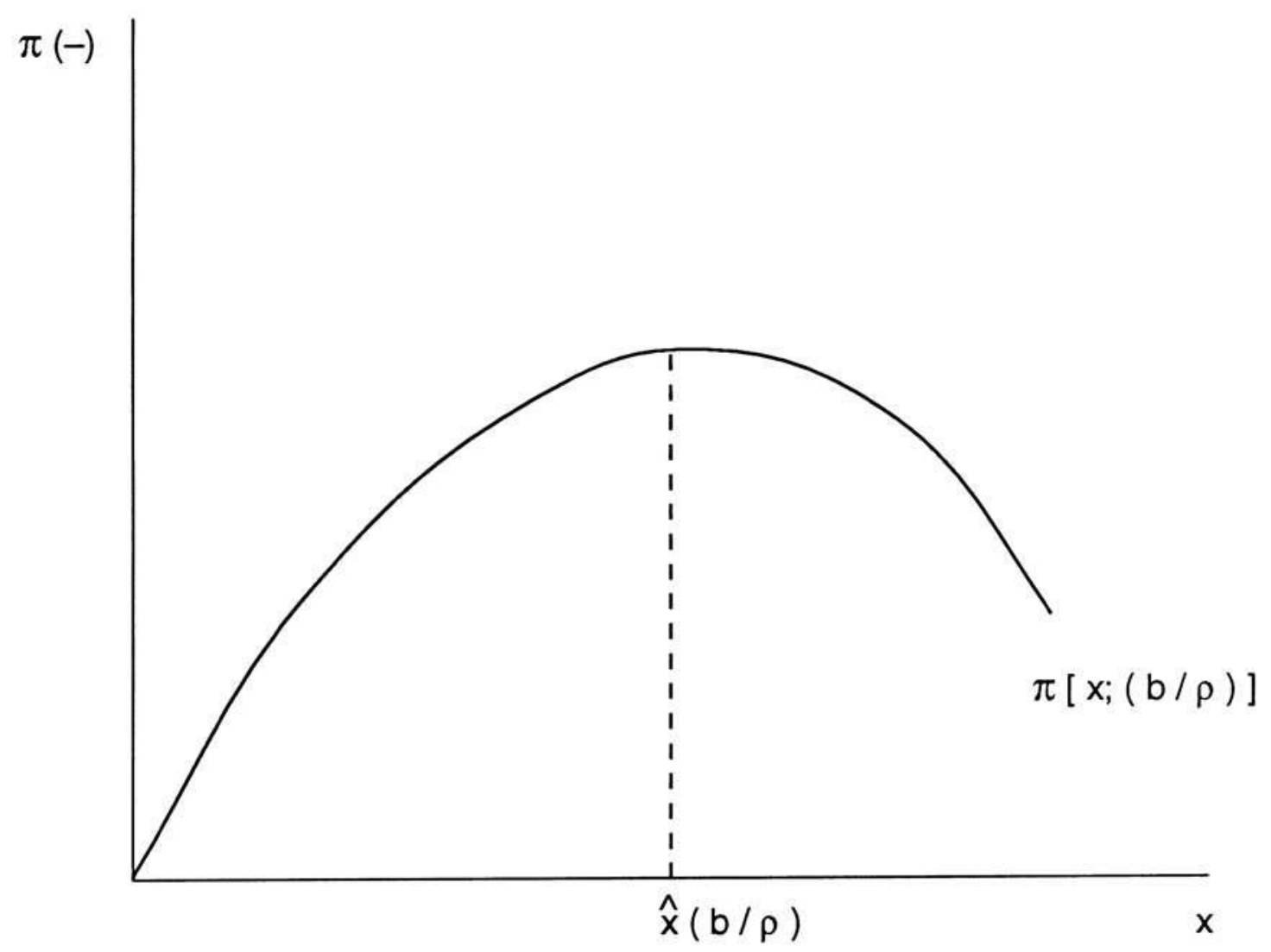


Figure 2.

THE CLOSED ECONOMY

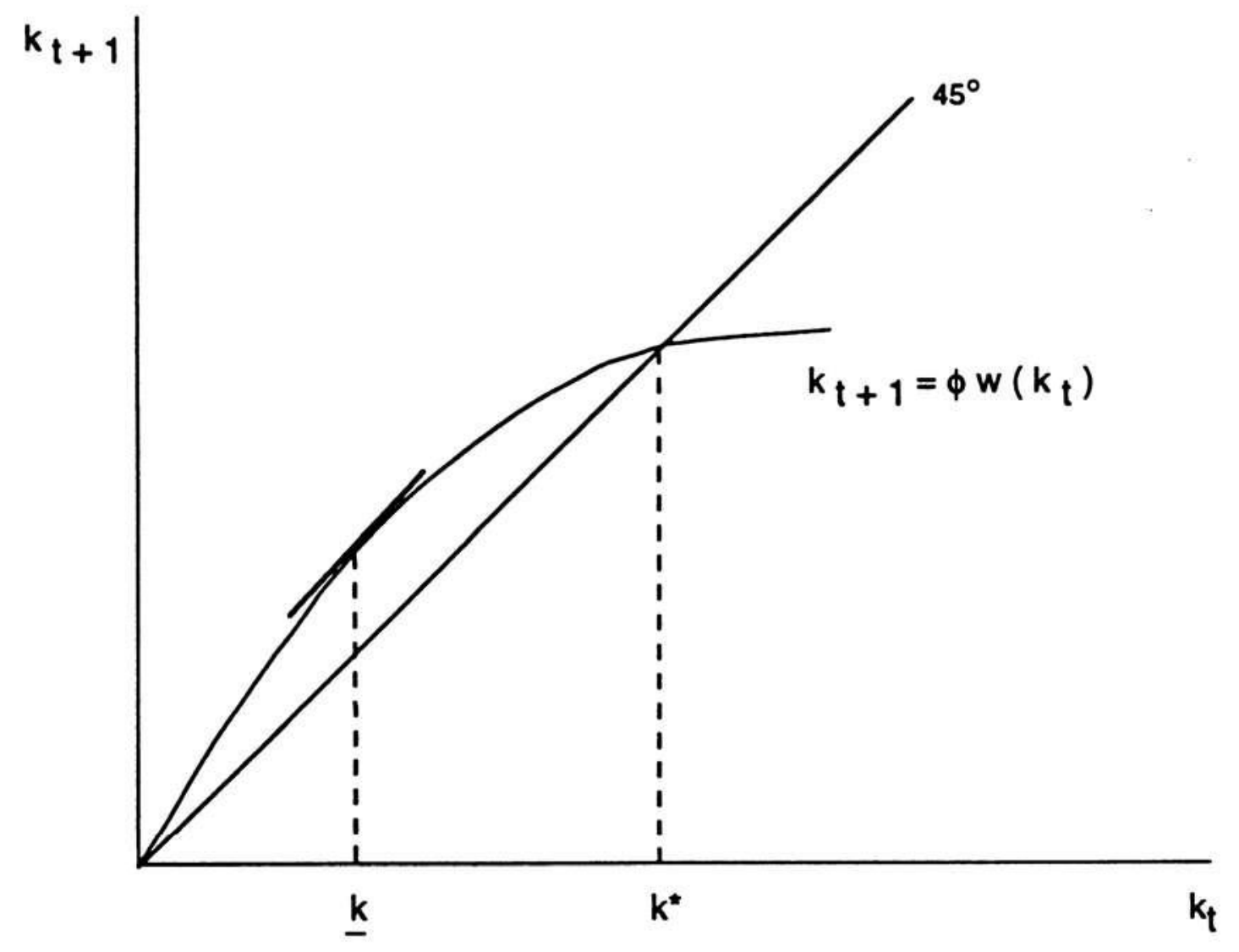


Figure 3

\section{THE H FUNCTION}

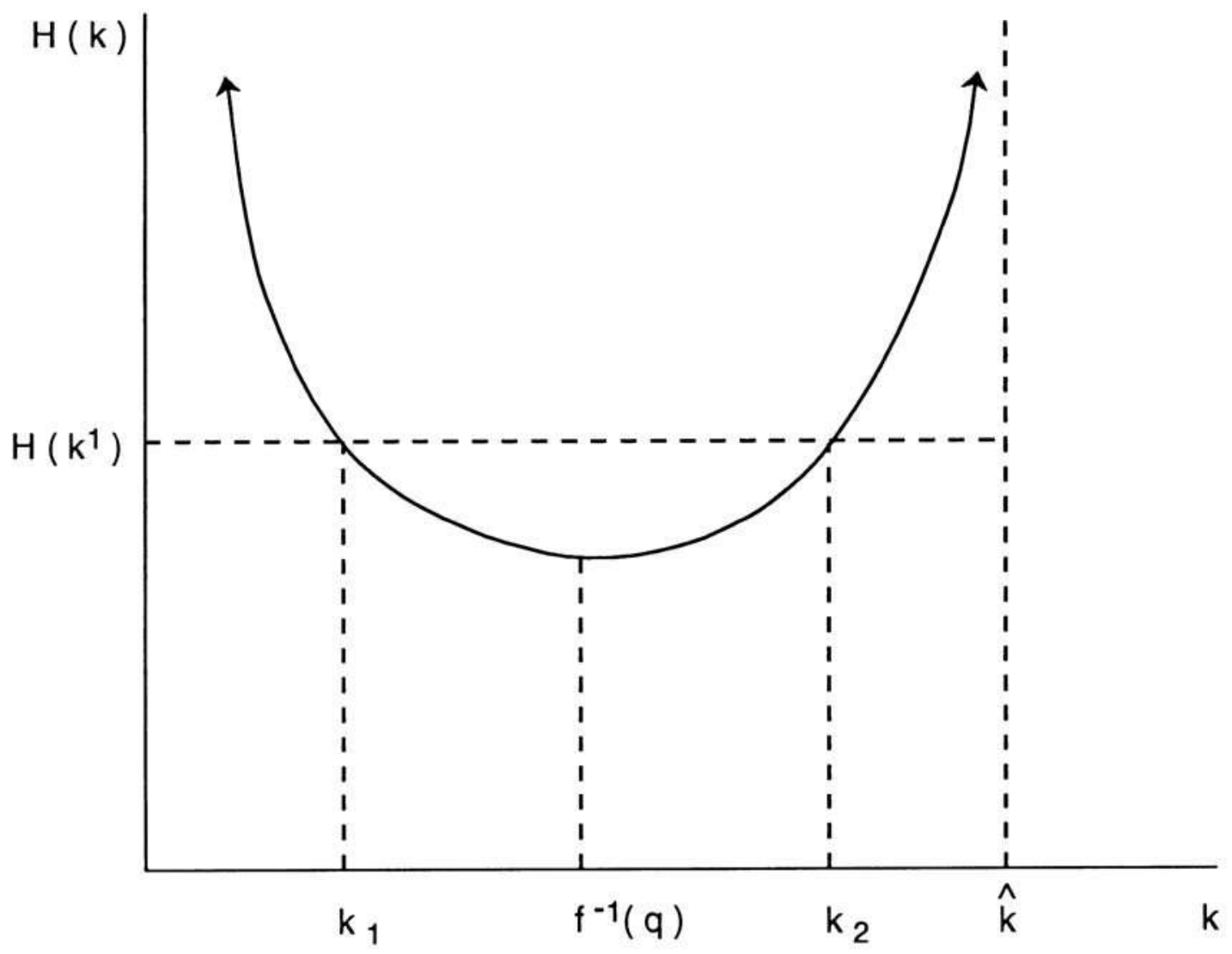


Figure 4

\section{STEADY STATES WITH OPEN ECONOMIES}

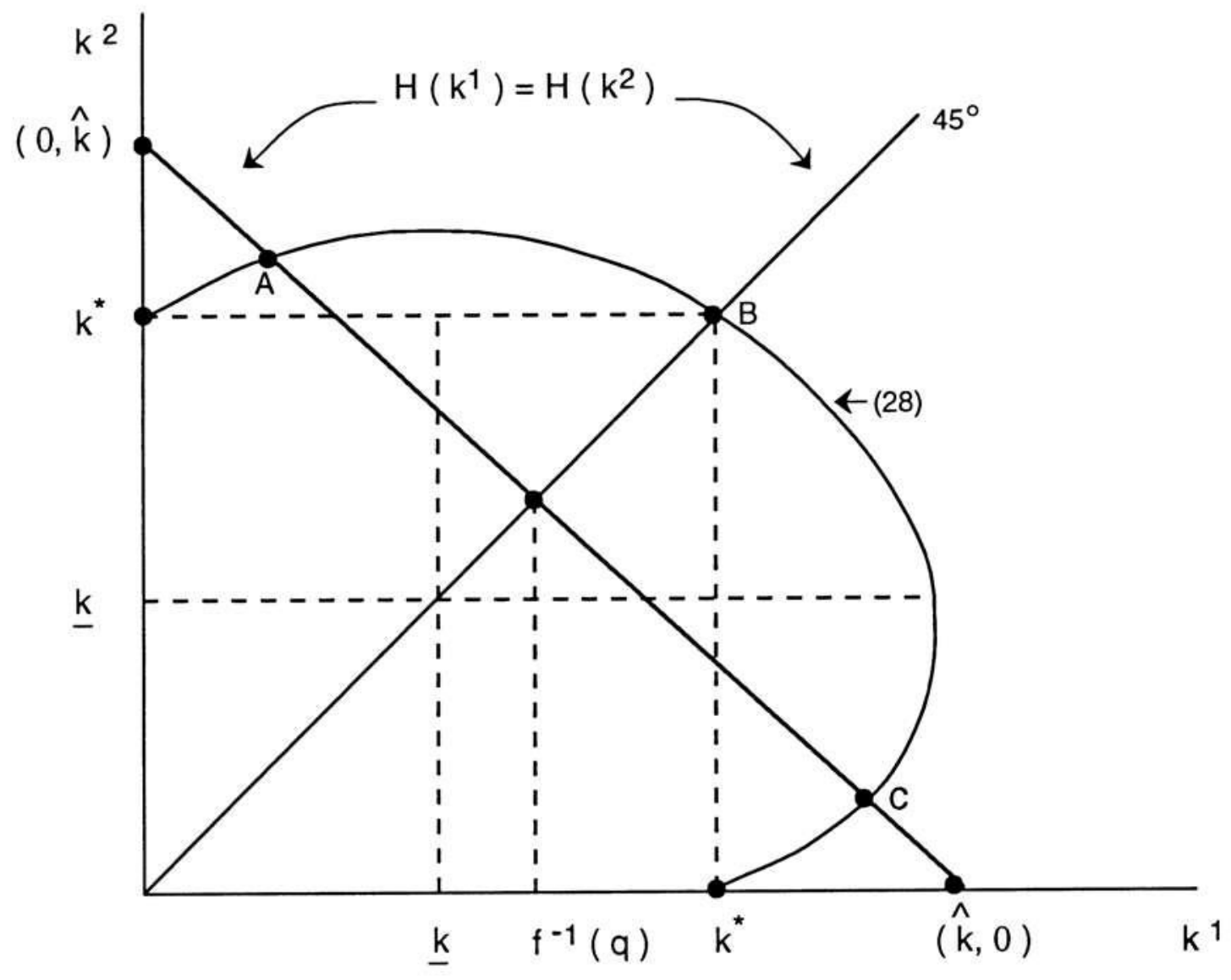




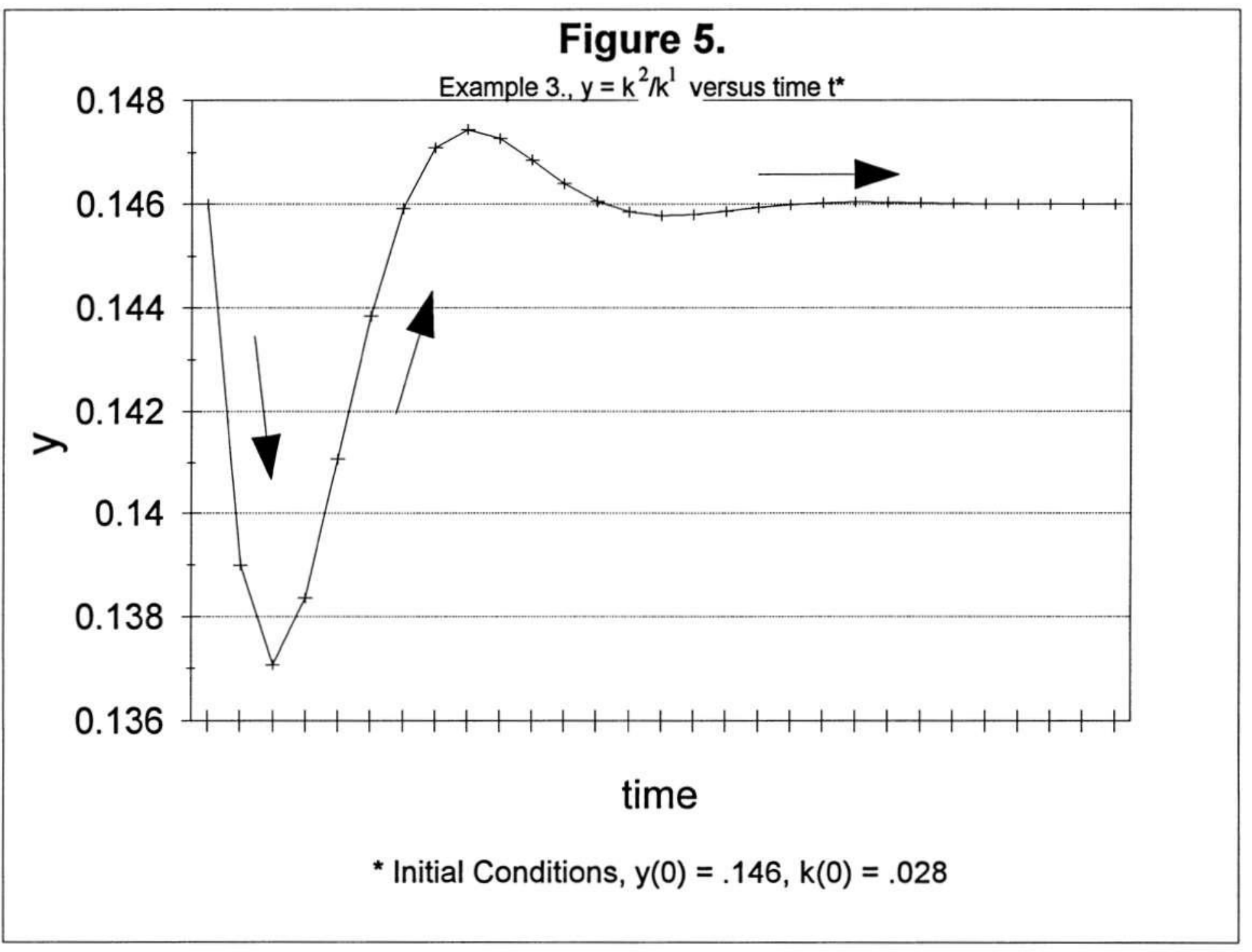


Figure 6 .

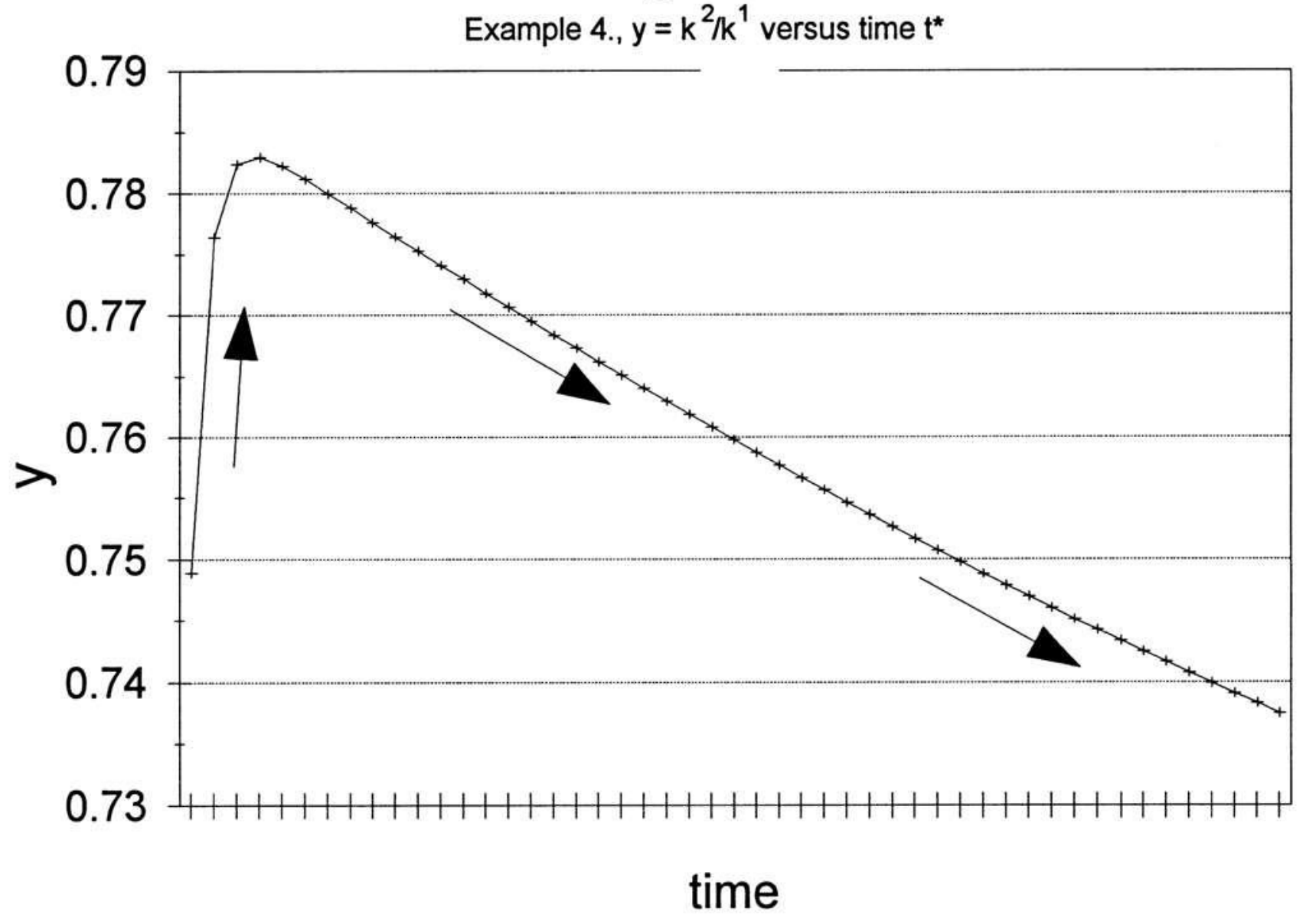

${ }^{*}$ Initial Conditions, $\mathrm{y}(0)=.749, \mathrm{k}(0)=.260$ 


\section{Figure Legends}

Figure 1:

The Expected Return Function

Figure 2:

The Closed Economy

Figure 3:

The H Function

Figure 4:

Steady States With Open Economies

Figure 5:

Example 3. $\mathrm{y}=\mathrm{k}^{2} / \mathrm{k}^{1}$ versus time 


\begin{tabular}{|c|c|}
\hline \multicolumn{2}{|c|}{ List of Symbols } \\
\hline 0 & zero \\
\hline 1 & one \\
\hline $\mathrm{K}$ & uppercase "kay" \\
\hline $\mathrm{k}$ & lowercase "kay" \\
\hline$\gamma$ & lowercase "gamma" \\
\hline$\rho$ & lowercase "rho" \\
\hline w & lowercase "double-you" \\
\hline$\in$ & "is an element of" \\
\hline$\pi$ & lowercase "pi" \\
\hline$\eta$ & lowercase "eta" \\
\hline$\alpha$ & lowercase "alpha" \\
\hline$\phi$ & lowercase "phi" \\
\hline$\mu$ & lowercase "mu" \\
\hline$\beta$ & lowercase "beta" \\
\hline$\infty$ & "infinity" \\
\hline$\lambda$ & lowercase "lambda" \\
\hline$\partial$ & denotes a partial derivativ \\
\hline
\end{tabular}

